\title{
Motor Nerve Arborization Requires Proteolytic Domain of Damage-Induced Neuronal Endopeptidase (DINE) during Development
}

\author{
Sakiko Matsumoto, @Sumiko Kiryu-Seo, and $\odot$ Hiroshi Kiyama \\ Department of Functional Anatomy and Neuroscience, Graduate School of Medicine, Nagoya University, Nagoya 466-8550, Japan
}

Damage-induced neuronal endopeptidase (DINE)/endothelin-converting enzyme-like 1 (ECEL1) is a membrane-bound metalloprotease, which we originally identified as a nerve regeneration-associated molecule. Abundant expression of DINE is observed in regenerating neurons, as well as in developing spinal motor neurons. In line with this, DINE-deficient (DINE KO) embryos fail to arborize phrenic motor nerves in the diaphragm and to form proper neuromuscular junctions (NMJ), which lead to death shortly after birth. However, it is unclear whether protease activity of DINE is involved in motor nerve terminal arborization and how DINE participates in the process. To address these issues, we performed an in vivo rescue experiment in which three types of motor-neuron specific DINE transgenic mice were crossed with DINE KO mice. The DINE KO mice, which overexpressed wild-type DINE in motor neurons, succeeded in rescuing the aberrant nerve terminal arborization and lethality after birth, while those overexpressing two types of protease domain-mutated DINE failed. Further histochemical analysis showed abnormal behavior of immature Schwann cells along the DINE-deficient axons. Coculture experiments of motor neurons and Schwann cells ensured that the protease domain of neuronal DINE was required for proper alignment of immature Schwann cells along the axon. These findings suggest that protease activity of DINE is crucial for intramuscular innervation of motor nerves and subsequent NMJ formation, as well as proper control of interactions between axons and immature Schwann cells.

Key words: branching; ECEL1; metalloprotease; motor neuron; neuromuscular junction; Schwann cell

Significance Statement

Damage-induced neuronal endopeptidase (DINE) is a membrane-bound metalloprotease; expression is abundant in developing spinal motor neurons, as well as in nerve-injured neurons. DINE-deficient $(\mathrm{KO})$ embryos fail to arborize phrenic motor nerves in the diaphragm and to form a neuromuscular junction, leading to death immediately after birth. To address whether proteolytic activity of DINE is involved in this process, we performed in vivo rescue experiments with DINE KO mice. Transgenic rescue of DINE KO mice was accomplished by overexpression of wild-type DINE, but not by protease domain-mutated DINE. Immature Schwann cells were abnormally aligned along the DINE protease-deficient axons. Thus, the protease activity of DINE is crucial for motor axon arborization, as well as the interaction between axons and immature Schwann cells.

\section{Introduction}

Damage-induced neuronal endopeptidase (DINE) is a membrane-bound metalloprotease that we originally identified as a nerve injury-associated gene (Kiryu-Seo et al., 2000). One of the hallmarks of DINE is acute and specific induction of mRNA ex-

\footnotetext{
Received 0ct. 18, 2015; revised March 10, 2016; accepted March 14, 2016.

Author contributions: S.K.-S. and H.K. designed research; S.M. and S.K.-S. performed research; S.M. and S.K.-S. analyzed data; S.M., S.K.-S. and H.K. wrote the paper.

This work was supported by Japan Society for the Promotion of Science Fellows Grant-in-Aid to S.M., Takeda Science Foundation, Japan Society for the Promotion of Science KAKENHI Grants 25430036 and 22500314 to S.K.-S., and Japan Society for the Promotion of Science KAKENHI Grant 23111007 to H.K. We thank Naomi Tawarayama, Yoshiko Itai, Noriko Usami, and Yoshiko Tabata for excellent assistance with animal care; Ayako Asano for secretarial assistance; and the technical staff in the Division for Research of Laboratory Animals, Center for Research of Laboratory Animals and Medical Research Engineering.

The authors declare no competing financial interests.
}

pression in neurons in the CNS and PNS in response to a variety of nerve injuries (Kiryu-Seo et al., 2000, 2008; Kato et al., 2002; Ohba et al., 2004). Under normal conditions, DINE is expressed exclusively in neurons, but not in glia; expression is localized to some neuronal subsets, such as cranial and spinal motor neurons, from early development (Nagata et al., 2006). Recently, intriguing evidence has shown that mutations in endothelin-converting enzyme-like 1 (ECEL1), a human homolog of DINE, cause autosomal-recessive congenital distal arthrogryposis type $5 \mathrm{D}$

Correspondence should be addressed to either Dr. Sumiko Kiryu-Seo or Dr. Hiroshi Kiyama, Department of Func tional Anatomy and Neuroscience, Graduate School of Medicine, Nagoya University, 65 Tsurumaicho, Showa-ku, Nagoya 466-8550, Japan. E-mail: skiryu@med.nagoya-u.ac.jp or kiyama@med.nagoya-u.ac.jp.

DOI:10.1523/JNEUROSCI.3811-15.2016

Copyright $\odot 2016$ the authors $\quad 0270-6474 / 16 / 364744-14 \$ 15.00 / 0$ 
(DA5D) (Dieterich et al., 2013; McMillin et al., 2013), suggesting that mutations or deletions of the DINE gene in the rodent are associated with the disease phenotype in humans. DINEdeficient (KO) mice, which we previously generated, die immediately after birth as a result of respiratory failure. The aberrant terminal arborization of phrenic motor nerves in the diaphragm and poor formation of the neuromuscular junction (NMJ) during the embryonic period were shown to be the reason for death (Nagata et al., 2010). Results from human and rodent studies suggest that DINE is involved in motor neuron development, in particular motor nerve arborization and NMJ formation.

In general, motor neurons develop in response to numerous proteins and peptides, whose activation is regulated by proteases, and innervate the appropriate position in the muscle (Roelink et al., 1995; Feng et al., 2000; Haase et al., 2002; Lieberam et al., 2005; Gatto et al., 2014). It is therefore likely that multiple proteolytic events are involved in motor neuron development. DINE belongs to the M13 family, whose member protein is a Type II membrane-associated endopeptidase, and its protease active site faces the lumen or extracellular side of membranes. Among the family members, neprilysin (NEP) and endothelin-converting enzyme (ECE) have been well studied, and potential substrates have already been identified as amyloid $\beta$ and big-endothelin, respectively (Yanagisawa et al., 1988; Iwata et al., 2000). A substrate of DINE has not yet been identified, although efforts have been devoted to identify one. However, results have shown that some membrane-bound metalloproteases, such as NEP and ADAM19, have different functions other than proteases (Sumitomo et al., 2005; Yumoto et al., 2008). ADAM19, which exhibits proteolytic activity for various ligands, including neuregulins, binds EphA4 and blocks internalization of the ephrinA5/EphA4 complex at the NMJ to stabilize the NMJ in a protease activityindependent manner (Yumoto et al., 2008). The question therefore arises whether DINE functions as a protease.

ErbB2/3 and neuregulin 1 (Nrg1) mutant mice lacking Schwann cell precursors (SCPs) show a similar phenotype to DINE KO mice, where motor axons project to target muscle, but lead to aberrant axon terminal arborization and subsequent axonal degeneration (Riethmacher et al., 1997; Lin et al., 2000; Wolpowitz et al., 2000; Yang et al., 2001). The Nrg/ErbB axis is considered to be most important for interactions between axons and Schwann cells during embryonic development (Birchmeier, 2009). Biologically active Nrg1 is generated by proteolytic shedding of membrane-bound metalloproteases from axons ( $\mathrm{Hu}$ et al., 2008; Freese et al., 2009; La Marca et al., 2011). In this context, it is likely that proteolytic processing is involved in regulating the interaction between axons and Schwann cells, although the events are complicated and the mechanisms involved remain to be shown.

To address these issues, we generated three types of mice in which either wild-type (WT) or protease-inactive DINE was transiently expressed in embryonic motor neurons with the DINE KO background. Using these mice, we demonstrated that protease domain of DINE was necessary for arborization of developing motor nerves and formation of the NMJ in vivo. We also provided possible insight that protease activity of DINE was involved in the interaction between axons and immature Schwann cells.

\section{Materials and Methods}

Animals and genotyping. For the generation of DINE transgenic mice ( $\mathrm{Tg}^{\mathrm{WT}}$, $\mathrm{Tg}^{\mathrm{mut}}$, and $\mathrm{Tg}^{\mathrm{E} 613 \mathrm{~V}}$ ) pHb9-MCS-IRES-EGFP was obtained from Addgene (\#16283). This plasmid contained a $\sim 9 \mathrm{~kb}$ fragment comprising the $5^{\prime}$ upstream region of the murine $\mathrm{Hb}$ gene (Arber et al., 1999), a $5^{\prime}$ splicing substrate (Choi et al., 1991), an internal ribosome entry sequence (IRES), EGFP, and a bovine polyA signal. Full-length DINE $\left(D I N E^{W T}\right)$ or two types of mutant DINEs (DINE ${ }^{m u t}$ or DINE $E^{E 613 V}$ ) was cloned into the PmeI/SpeI site. DINE ${ }^{\text {mut }}$ was constructed by a deletion of five amino acids in the putative active site of DINE (His-Glu-Leu-Thr-His at amino acid positions 612616 ), and a conversion of Glu ${ }^{672}$ to Val. DINE ${ }^{\mathrm{E} 613 \mathrm{~V}}$ was constructed by a conversion of $\mathrm{Glu}^{613}$ to Val. Transgenic constructs were linearized and fragmented $(\sim 14 \mathrm{~kb})$ using XhoI before pronuclear injections into BDF1 fertilized oocytes (SLC). Founders for Hb9:DINE ${ }^{W T}$-EGFP (Tg WT), Hb9: $D I N E^{m u t}$-EGFP (Tg $\left.{ }^{\text {mut }}\right)$, and $H b 9: D I N E^{E 613 V}$-EGFP $\left(\mathrm{Tg}^{\mathrm{E} 613 \mathrm{~V}}\right)$ transgenic mice were identified by PCR using transgene-specific primers: 5 '-GATGC-

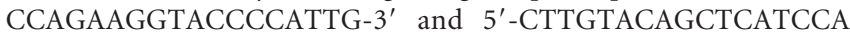
TGCC-3'. The lines that expressed EGFP specifically in embryonic spinal motor neurons were selected.

DINE KO mice have been previously generated (Nagata et al., 2010) and maintained on a C57BL/6 background. To obtain DINE KO mice carrying either transgene (KO; $\mathrm{Tg}^{\mathrm{WT}}, \mathrm{KO} ; \mathrm{Tg}^{\text {mut }}$, or $\left.\mathrm{KO} ; \mathrm{Tg}^{\mathrm{E} 613 \mathrm{~V}}\right), \mathrm{Tg}^{\mathrm{WT}}, \mathrm{Tg}^{\text {mut }}$, or $\mathrm{Tg}^{\mathrm{E} 613 \mathrm{~V}}$ mice was crossed with DINE heterozygous (het) mice, and DINE het; $\mathrm{Tg}^{\text {WT }}$, DINE het;Tg ${ }^{\text {mut }}$, or DINE het; $\mathrm{Tg}^{\mathrm{E} 613 \mathrm{~V}}$ male offspring were used in timed mating with DINE het females. Noon on day of detection of the vaginal plug was considered to be embryonic day 0.5 (E0.5). Pregnant mice were anesthetized and embryos were removed from the dams. Tail lysate was used for genotyping with the above-described transgene-specific primers and DINE targeting allele-specific primers: $5^{\prime}$-CCCCACCAGCCCCGGT TATGTTATCC-3', 5' -GCTGGGGGACAGGTGGGAGCTGATGA-3', and 5'-CGCATCGCCTTCTATCGCCTTCTTGACGAG-3'.

All animal protocols were performed in accordance with the University Animal Committee Guidelines for the care and use of laboratory animals and were approved by the Nagoya University Institutional Animal Care and Use Committee. All possible efforts were made to minimize suffering.

Immunohistochemistry. For cryosections, E15.5-E17.5 embryos were removed from pregnant mice. Embryos and spinal cord at postnatal day 8 were immersed in $4 \%$ PFA in phosphate buffer (PB) at $4^{\circ} \mathrm{C}$ overnight or were fresh-frozen in powdered dry ice. The samples were embedded in OCT compound and cut into serial $16-\mu \mathrm{m}$-thick sections using a cryostat. Adult mice were transcardially perfused with $2 \%$ PFA in PB containing $0.2 \%$ picric acid, and dissected diaphragm was cut into free-floating $30-\mu \mathrm{m}$-thick sections. For paraffin sections, dissected diaphragms from E17.5 embryos were dehydrated, embedded in paraffin, and cut into serial $4-\mu \mathrm{m}$-thick sections.

The fresh-frozen sections were fixed in 2\% PFA in PB for $20 \mathrm{~min}$ and washed before blocking. Paraffin sections were subjected to antigen retrieval by boiling in citrate buffer, $\mathrm{pH} 6.0$, for $10 \mathrm{~min}$ and washed before blocking. All the sections were incubated in blocking buffer (1\% BSA, $0.3 \%$ Triton X-100 in PB) for $1 \mathrm{~h}$, followed by $4^{\circ} \mathrm{C}$ overnight incubation with primary antibodies: goat anti-DINE (ECEL1; 1:1000, Santa Cruz Biotechnology, PRID: AB_2097871) and rabbit anti-Oct-6 (1:500, Abcam, PRID: AB_11130256), antibodies for fresh-frozen sections, rabbit anti-GFP (1:1000, MBL, PRID: AB_591819), goat anti-ChAT (1:200, Millipore, PRID: AB_262156), and rabbit anti-PGP 9.5 (1:1000, UltraClone, AB_2313685) antibodies for fixed sections, and rabbit anti-p75 (1:1000, Promega, PRID: AB_430853) and mouse anti-neurofilament 200 (1:1000, Sigma-Aldrich, PRID: AB_260781) antibodies for paraffin sections. After rinsing with PBS, sections were incubated with AlexaFluor-488- or AlexaFluor-594-conjugated secondary antibodies (1:1000, Invitrogen), DAPI (1:10,000, Dojindo), or AlexaFluor-594conjugated $\alpha$-bungarotoxin (BTX; 1:500, Invitrogen) in PBS at room temperature for $2 \mathrm{~h}$. Following another wash step, the sections were mounted and visualized by a fluorescent microscope (BX53 and FV10i; Olympus).

Whole-mount immunohistochemistry. Whole-mount immunohistochemistry was performed as previously described (Nagata et al., 2010). Briefly, E13.5-17.5 embryos were removed from the pregnant mice and immersed in $2 \%$ PFA at $4^{\circ} \mathrm{C}$ overnight. Diaphragm and latissimus dorsi (LD) were dissected, washed with $\mathrm{PB}$, and incubated with $0.1 \mathrm{M}$ glycine in PB for $1 \mathrm{~h}$. After rinsing with $0.5 \%$ Triton X-100 in PBS, the muscles were incubated in blocking buffer (3\% BSA, 5\% NGS, $1 \%$ Triton X-100, $0.5 \mathrm{M}$ $\mathrm{NaCl}$ in $0.01 \mathrm{M} \mathrm{PB}$ ) at room temperature for $4 \mathrm{~h}$, and then incubated with 
rabbit anti-peripherin (1:1000, Millipore, PRID: AB_90725) in blocking buffer at $4^{\circ} \mathrm{C}$ overnight. After washing with $0.5 \%$ Triton X-100 in PBS, the muscles were incubated with AlexaFluor-488-conjugated secondary antibody (1:500) and AlexaFluor-594-conjugated BTX (1:300) at $4^{\circ} \mathrm{C}$ overnight. The muscles were then rinsed in $0.5 \%$ Triton X-100 in PBS and were visualized using a fluorescent microscope (BZ9000; Keyence).

Subcellular fractionation and Western blotting. Ventral portion of spinal cord from E13.5 embryo was homogenized in hypotonic buffer (10 mM Tris- $\mathrm{HCl}, \mathrm{pH} 7.5,1 \mathrm{~mm} \mathrm{MgCl}_{2}, 0.25 \mathrm{~m}$ sucrose, and 0.1 mM PMSF) and centrifuged at $8000 \times g$ for $10 \mathrm{~min}$. The resulting supernatant was centrifuged at $105,000 \times g$ for $1 \mathrm{~h}$ in a Beckman TLA 55 rotor (Beckman Coulter). The pellet dissolved in hypotonic buffer (membrane fraction) and supernatant (cytosol fraction) were assayed by SDS-PAGE followed by Western blotting. For subcellular fractionation, the membrane fraction was loaded onto the top of a sucrose step gradient comprised of 0.6 $\mathrm{ml}$ of $2.0 \mathrm{M}$ sucrose, $0.8 \mathrm{ml}$ of $1.5 \mathrm{M}$ sucrose, $0.8 \mathrm{ml}$ of $1.0 \mathrm{M}$ sucrose, and $0.8 \mathrm{ml}$ of $0.5 \mathrm{M}$ sucrose prepared in $10 \mathrm{~mm}$ Tris- $\mathrm{HCl}, \mathrm{pH} 7.5$. The gradients were centrifuged at $28,000 \mathrm{rpm}$ for $2 \mathrm{~h}$ in a Beckman SW41Ti rotor (Beckman Coulter). Eleven $350 \mu \mathrm{l}$ of fractions were collected from top of the gradient and were analyzed by Western blotting. The following antibodies were used: anti-DINE, anti-GFP, rabbit anti-calreticulin (1:2000, Thermo Fisher Scientific, PRID: AB_325990), mouse anti-N-cadherin (1:2000, BD Biosciences, PRID: AB_2077527), and rabbit anti-MEK1/2 (1:1000, Cell Signaling, PRID: AB_10695880) antibodies and HRPconjugated secondary antibodies (1:5000, GE Healthcare).

Semithin diaphragm sections. E17.5 embryos were removed from pregnant mice, perfused with $2.5 \%$ glutaraldehyde in $0.1 \mathrm{M} \mathrm{PB}$, and postfixed with $2 \%$ osmium tetraoxide in $0.1 \mathrm{M} \mathrm{PB}$ for $1 \mathrm{~h}$ at $4^{\circ} \mathrm{C}$. Dissected diaphragms were dehydrated and embedded in Durcupan ACM Fulka (Sigma-Aldrich). Then, $1-\mu \mathrm{m}$-thick semithin sections were cut using a glass knife, stained with $1 \%$ toluidine blue, and examined by light microscope (BX41; Olympus).

Digoxigenin (DIG)-labeled in situ hybridization. The DIG-labeled RNA probe for Oct-6 was prepared using T7 polymerase (Promega), and the DIG RNA Labeling Mix (Roche). In situ hybridization was performed as previously described (Matsumoto et al., 2012). Briefly, fresh-frozen sections were fixed in $4 \% \mathrm{PFA}$, treated with $\mathrm{HCl}$ and proteinase $\mathrm{K}$ (Roche), acetylated, and dehydrated. Sections were incubated with DIG-labeled Oct- 6 antisense RNA probe in $50 \%$ formamide at $50^{\circ} \mathrm{C}$ overnight. After washing with standard saline citrate buffer, the sections were treated with RNase, washed again, and incubated with alkaline phosphataseconjugated anti-DIG Fab fragments (1:2000, Roche) in blocking buffer (Roche) at $4^{\circ} \mathrm{C}$ overnight. After rinsing, the signals were developed using alkaline phosphatase substrate.

$R N A$ preparation and $q R T-P C R$. Total RNA was extracted from sciatic nerves of 12 embryos at E18.5 using RNeasy Lipid Tissue Mini Kit (QIAGEN). Total RNA was converted to cDNA with Superscript Reverse Transcriptase III (Invitrogen) and nucleotide oligo-dT. Quantitative PCR was performed on a StepOnePlus unit (Applied Biosystems) using SYBR Green PCR Master Mix (Applied Biosystems). The following primers were used: Oct-6 forward: 5'-GTTCTCGCAGACCACCATCT-3'; Oct-6 reverse: 5'-GTCTCCTCCAGCCACTTGTT-3'; Sox10 forward: 5' -AGATGGGAAC CCAGAGCAC-3'; Sox10 reverse: 5'-CTCTGTCTTTGGGGTGGTTG-3'; NFATc4 forward: 5' -GAGCAGCTGGAGCTGAGG-3'; NFATc4 reverse: 5' TGTAGCCTAGGAGCTTGAC-3'; Id 2 forward: 5'-TGAACGACTGC TACTCCAAGCTCA-3'; Id2 reverse: 5'-GTGCTGCAGGATTTCCATCT TGGT-3'; Id4 forward: 5'-GCAGTGCGATATGAACGACTGCTA-3'; Id4 reverse: $5^{\prime}$-TAACGTGCTGCAGGATCTCCACTT- ${ }^{\prime}$; HDAC1 forward: $5^{\prime}$ GTGGCCCTGGACACAGAGAT-3'; HDAC1 reverse: 5'-GCTTG AAATCCGGTCCAAAGT-3'; HDAC2 forward: $5^{\prime}$-TGAAATTAAACC GGCAACAAACT-3'; HDAC2 reverse: 5'-CAGAACCCTGATGCTTCT GACTT-3'; Dnmt1 forward: 5' -CTAGTTCCGTGGCTACGAGG-3'; Dnmt1 reverse: $5^{\prime}$-AGTTCCCCTCTTCCGACTCT-3'; Dnmt3a forward: 5'-GCGGGAGGATGATCGAAAGG-3'; Dnmt3a reverse: 5'-GGGGTGT CACTGCTTTCCAC-3'; Dnmt $3 b$ forward: $5^{\prime}$-CCCATCCATAGTGCCT TGGG-3'; Dnmt3b reverse: 5'-AATGCACTCCTCATACCCGC-3'; cyclinD1 forward: 5' -GCGTACCCTGACACCAATCT-3'; cyclinD1 reverse: $5^{\prime}$ CACAACTTCTCGGCAGTCAA-3'; cyclinE1 forward: 5'-GCGAG GATGAGAGCAGTTC-3'; cyclinE1 reverse: 5'-AAGTCCTGTGCCAAG
TAGAAC-3'; $C d k 4$ forward: $5^{\prime}$-ATGGCTGCCACTCGATATGAA-3'; Cdk4 reverse: 5'-TCCTCCATTAGGAACTCTCACAC-3'; Cdk6 forward: 5'-GGCGTACCCACAGAAACCATA-3'; Cdk6 reverse: 5'-AGGTA AGGGCCATCTGAAAACT-3'; Cdk2 forward: 5'-CCTGCTTATCAATG CAGAGGG-3'; Cdk2 reverse: 5'-TGCGGGTCACCATTTCAGC-3'; p21 forward: 5'-CCTGGTGATGTCCGACCTG-3'; p21 reverse: $5^{\prime}$-CCAT GAGCGCATCGCAATC-3'; actin forward: $5^{\prime}$-GCCTTCCTTCTTGGG TATG-3'; actin reverse: 5'-ACCACCAGACAGCACTGTG-3'.

Coculture of motor neurons and Schwann cells. E12.5 embryos were transferred into L15 medium (Sigma-Aldrich), and their tails were used for genotyping. The ventral portion of the spinal cord, which contains motor neurons, was dissected, minced, and collected in L15 medium. Collected tissue was dissociated by trypsin (Invitrogen) and DNaseI (Roche) and subsequently triturated. The suspension, including motor neuron, was then transferred to poly-L-lysin-laminin-coated glasses in 24-well plate containing Neurobasal medium (2\% B27, Glutamax, P/S, $10 \mu \mathrm{g} / \mathrm{ml}$ of BDNF, GDNF, CNTF, NT3, and NGF) and incubated at $37^{\circ} \mathrm{C}$. After $5 \mathrm{~d}$, the motor neurons were either fixed in 4\% PFA for immunocytochemistry or were cocultured with Schwann cells. For Schwann cell primary cultures, postnatal day (P) 2 Sprague-Dawley rats were killed and sciatic nerves were dissected. The nerves were incubated with $1 \mathrm{mg} / \mathrm{ml}$ collagenase in PBS for $40 \mathrm{~min}$ and were subsequently trypsinized, and triturated in DMEM, followed by an overnight incubation in DMEM (10\% FBS, P/S). The following day, the medium was exchanged to DMEM (10\% FBS, P/S, $10 \mu \mathrm{M} \mathrm{AraC)}$ ). After $6 \mathrm{~d}$, the cells were subcultured in DMEM (10\% FBS, P/S, $10 \mu \mathrm{M}$ forskolin) in poly-Dlysin-coated dishes for cell proliferation. Forskolin was removed from the medium after the cells were confluent. For the coculture experiment, the proliferated Schwann cells were added to the motor neuron mixed culture. After $2 \mathrm{~d}$, the cocultured cells were fixed with 4\% PFA and immunostained. The following antibodies were used for immunocytochemistry: mouse anti-neurofilament (2H3, 1:1000, DSHB, PRID: AB_531793) and rabbit anti-S100 (1:1000, DAKO, PRID: AB_10013383) antibodies.

BrdU incorporation assay. Pregnant mice at E13.5 and E16.5 were intraperitoneally injected with $100 \mu \mathrm{g}$ BrdU per gram of body weight. One hour later, the embryos were dissected and frozen in powdered dry ice, and their tails were used for genotyping. Cryosections of embryos were fixed in methanol, denatured with $2 \mathrm{~N} \mathrm{HCl}$ at $37^{\circ} \mathrm{C}$ for $20 \mathrm{~min}$, and neutralized in $0.1 \mathrm{M}$ sodium borate, $\mathrm{pH} 8.5$, for $10 \mathrm{~min}$. After incubating in blocking buffer (1\% BSA, $0.3 \%$ Triton X-100 in PB) at room temperature for $1 \mathrm{~h}$, the sections were immunostained using rat anti-BrdU (1:200, AbD Serotec, PRID: AB_609567) antibody and DAPI.

Quantification of nerve arborization. For quantification of embryonic phrenic and thoracodorsal nerve elongation, we determined the total length of nerves using whole-mount immunostained diaphragm and LD that were stained with anti-peripherin antibody. We defined the point at which the nerve trunk penetrated muscles and initially branched as the "branching point." All branches distal to the branching point were traced, and the length of each branch was measured using ImageJ (National Institutes of Health, Bethesda, MD) and summed to determine total length. For quantification of the complexity of phrenic nerve arborization, we performed a Sholl analysis using peripherin-stained hemidiaphragm samples (right side). The concentric circles, whose center was located at a branching point, were spaced $0.1 \mathrm{~mm}$ apart, and the number of intersections by a phrenic nerve was quantified. For quantification of the complexity of thoracodorsal nerve arborization, we counted the cross point of nerve terminal branches where each branch subdivided or merged using peripherin-immunostained LD.

\section{Results}

\section{Generation of DINE transgenic mice}

DINE expression is especially abundant in embryonic spinal motor neurons (Fig. 1A) (Nagata et al., 2006). As described in our previous work (Nagata et al., 2010), whole-mount immunohistochemical staining using anti-peripherin antibody and BTX as markers for embryonic nerve and acetylcholine receptors in the NMJ, respectively, reveal that phrenic motor nerves reach 
branching points in the diaphragm to arborize and form the NMJ during the prenatal stage in WT mice (Fig. 1A). Conversely, DINE KO embryos exhibit aberrant arborization of phrenic motor nerves and abnormal formation of the NMJ in the diaphragm, leading to death immediately after birth. In the present study, we attempted to determine whether DINE protease activity was a requirement for nerve arborization by using the DINE KO mouse. We first generated two types of DINE transgenic mice (DINE Tg) for an in vivo rescue experiment: mice overexpressing WT DINE (Hb9:DINE ${ }^{W T} \mathrm{Tg}$ mouse $\left(\mathrm{Tg}^{\mathrm{WT}}\right)$ ) and mice overexpressing mutated DINE without putative protease activity ( $\mathrm{Hb}$ : $D I N E^{\text {mut }} \mathrm{Tg}$ mouse $\left(\mathrm{Tg}^{\mathrm{mut}}\right)$ ). In the construct, exogenous DINE was followed by IRES and EGFP under control of the Hb9 promoter, which drove specific expression in spinal motor neurons during development (Fig. 1B). To obtain the protease inactive type of DINE (DINE ${ }^{\text {mut }}$ ), we deleted His-Glu-Leu-Thr-His at the position of 612-616 amino acids and converted $\mathrm{Glu}^{672}$ to Val. The amino acid alignment around the His-Glu-Leu-Thr-His motif is highly conserved among the M13 family members of metalloendopeptidase (Turner and Tanzawa, 1997). Previous studies have shown that mutations in the active site and conserved Glu residue at $\mathrm{C}$ terminus abolish protease activity (Devault et al., 1988a, b; Le Moual et al., 1991; Shimada et al., 1996).

We obtained 8 and 10 founders of $\mathrm{Tg}^{\mathrm{WT}}$ and $\mathrm{Tg}^{\text {mut }}$ mice, respectively. From these founders, we selected one line each (line \#5 for $\mathrm{Tg}^{\mathrm{WT}}$ and line $\# 3$ for $\mathrm{Tg}^{\mathrm{mut}}$ ), which transmitted the transgene and expressed comparable levels of GFP in the embryonic spinal cord. We then examined the expression pattern of exogenous GFP protein in $\mathrm{Tg}^{\mathrm{WT}}$ and $\mathrm{Tg}^{\mathrm{mut}}$ mice. Immunohistochemical staining showed intense GFP signals in the ventral horn of the embryonic spinal cord in both $\mathrm{Tg}^{\mathrm{WT}}$ and $\mathrm{Tg}^{\mathrm{mut}}$ mice. The signals colocalized with ChAT, a motor neuron marker (Fig. 1C). More than $85 \%$ of ChAT-positive motor neurons expressed GFP in the spinal cord in both $\mathrm{Tg}^{\mathrm{WT}}$ and $\mathrm{Tg}^{\mathrm{mut}}$ mice $(90.9 \pm 3.5 \%$ and $85.0 \pm 0.2 \%$, respectively) (Fig. $1 D$ ). The expression of DINE protein was observed in the membrane fraction in $\mathrm{WT}, \mathrm{Tg}^{\mathrm{WT}}$, and $\mathrm{Tg}^{\mathrm{mut}}$ mice (Fig. 1E). DINE protein expression levels in $\mathrm{Tg}^{\mathrm{WT}}$ and $\mathrm{Tg}^{\mathrm{mut}}$ were similar and more abundant than in WT mice, although exogenous GFP expression in the cytosol fraction was slightly increased in $\mathrm{Tg}^{\text {mut }}$ mice compared with $\mathrm{Tg}^{\mathrm{WT}}$ mice. Using these membrane fractions from $\mathrm{Tg}^{\mathrm{WT}}$ and $\mathrm{Tg}^{\text {mut }}$, the detailed subcellular localization of DINE protein was examined by sucrose density gradient fractionation (Fig. $1 F$ ). The result revealed that both $\mathrm{Tg}^{\mathrm{WT}}$ and $\mathrm{Tg}^{\mathrm{mut}}$ expressed DINE similarly in the ER (calreticulin-positive fractions) and the plasma membrane (N-cadherin-positive fractions), although the samples included endogenous and exogenous DINE proteins (Fig. $1 F$ ). We also confirmed that both exogenous DINE ${ }^{\mathrm{WT}}$ and DINE ${ }^{\text {mut }}$ showed the same subcellular localization in COS-7 cells (data not shown). The data suggest that DINE ${ }^{\text {mut }}$ maintains proper protein conformation. To further examine the effect of additional overexpression of DINE ${ }^{\mathrm{WT}}$ or DINE ${ }^{\text {mut }}$ on phrenic motor nerve arborization, we prepared whole-mount stainings of the diaphragm from $\mathrm{Tg}^{\mathrm{WT}}$ and $\mathrm{Tg}^{\text {mut }}$ embryos (Fig. $1 G$ ). Results showed no obvious difference in nerve terminal arborization between $\mathrm{Tg}^{\mathrm{WT}}$ and $\mathrm{Tg}^{\mathrm{mut}}$ mice, and the total length of phrenic nerves in the diaphragm was similar among $\mathrm{WT}, \mathrm{Tg}^{\mathrm{WT}}$, and $\mathrm{Tg}^{\text {mut }}$ mice (Fig. $1 H$ ). These results indicated that $\mathrm{Tg}^{\mathrm{WT}}$ and $\mathrm{Tg}^{\mathrm{mut}}$ mice expressed sufficient and similar levels of exogenous DINE and that neither DINE ${ }^{\text {WT }}$ nor DINE ${ }^{\text {mut }}$ overexpression affected arborization of phrenic motor nerves.

\section{Protease activity-deficient DINE failed to rescue abnormalities in DINE KO mice}

To examine whether DINE protease activity was required for motor nerve arborization, we generated DINE KO mice carrying either of the transgenes ( $\mathrm{KO}$; $\mathrm{Tg}^{\mathrm{WT}}, \mathrm{KO}$; $\mathrm{Tg}^{\mathrm{mut}}$ ) for the in vivo rescue experiment. As expected, whole-mount peripherin staining of the diaphragm at the embryonic stage of E13.5E17.5 demonstrated striking differences between KO; ${ }^{\text {WT }}$ and $\mathrm{KO} ; \mathrm{Tg}^{\text {mut }}$ mice, which overexpressed either DINE ${ }^{\mathrm{WT}}$ or DINE $^{\text {mut }}$ in the KO mice. As shown in Figure $2 A$, phrenic nerves from $\mathrm{KO} ; \mathrm{Tg}^{\mathrm{WT}}$ mice reached branching points, arborized, and formed the NMJ, although the KO phenotype was not completely rescued by exogenous DINE ${ }^{\mathrm{WT}}$ expression. Conversely, $\mathrm{KO} ; \mathrm{Tg}^{\text {mut }}$ mice did not show any apparent arborization of phrenic nerves after reaching the branching point. The $\mathrm{KO} ; \mathrm{Tg}^{\text {mut }}$ phenotype was completely consistent with the KO mice throughout the embryonic stage. We subsequently quantified the total length of phrenic nerves by tracing nerves (Fig. $2 B$ ) and the complexity of nerve arborization using the Sholl assay (Fig. 2C). Total length and complexity of phrenic nerves at E17.5 showed no significant differences between WT and $\mathrm{KO} ; \mathrm{Tg}^{\mathrm{WT}}$ mice, although total length at earlier embryonic days (E13.5-E15.5) was slightly decreased in $\mathrm{KO} ; \mathrm{Tg}^{\mathrm{WT}}$ mice compared with WT mice $(p<0.05)$. The KO; $\mathrm{Tg}^{\text {mut }}$ mice completely lost nerve length and complexity, which was similar to the KO mice. Expression of exogenous DINE protein in the embryonic spinal cord of both $\mathrm{KO} ; \mathrm{Tg}^{\mathrm{WT}}$ and $\mathrm{KO} ; \mathrm{Tg}^{\text {mut }}$ mice was examined using DINE antibody, and expression of exogenous DINEs was immunohistochemically identified (Fig. 2D). To confirm whether a subset of motor neurons innervating the diaphragm within the motor neuron pool expressed exogenous DINE, we used octamer-binding transcription factor 6 (Oct-6/Pou3f1/Scip) as a marker of phrenic motor neurons, as previously described (Philippidou et al., 2012). Although Oct-6 positive phrenic motor neurons expressed exogenous DINE in KO; $\mathrm{Tg}^{\mathrm{WT}}$ and $\mathrm{KO} ; \mathrm{Tg}^{\mathrm{mut}}$ mice, expression was slightly less than in WT mice (Fig. 2D), which probably led to a moderate rescue effect of the KO phenotype in $\mathrm{KO} ; \mathrm{Tg}^{\mathrm{WT}}$ mice. To further quantify cell number of motor neurons, we counted ChAT-positive motor neurons in the spinal cord at E17.5. Results showed no significant difference in cell number between $\mathrm{WT}, \mathrm{KO}, \mathrm{KO} ; \mathrm{Tg}^{\mathrm{WT}}$, and $\mathrm{KO} ; \mathrm{Tg}^{\mathrm{mut}}$ mice (Fig. 2E). These findings suggested that DINE protease activity is critical to form proper arborization of phrenic nerves, which is essential for diaphragm function.

Additionally, differences in lethality were apparent immediately after birth between $\mathrm{KO} ; \mathrm{Tg}^{\mathrm{WT}}$ and $\mathrm{KO} ; \mathrm{Tg}^{\mathrm{mut}}$ mice. During the embryonic stage, all genotypes, including $\mathrm{KO}, \mathrm{KO} ; \mathrm{Tg}^{\mathrm{WT}}$, and $\mathrm{KO} ; \mathrm{Tg}^{\mathrm{mut}}$, were seen in a normal Mendelian manner. However, all $\mathrm{KO}$ and $\mathrm{KO} ; \mathrm{Tg}^{\mathrm{mut}}$ pups exhibited cyanosis and died within 30 min after birth. Pups of other genotypes, including $\mathrm{KO} ; \mathrm{Tg}^{\mathrm{WT}}$, were viable (Fig. $3 A, B$ ). Next, we examined the survival rate of WT, KO, KO; $\mathrm{Tg}^{\mathrm{WT}}$, and $\mathrm{KO} ; \mathrm{Tg}^{\mathrm{mut}}$ mice from E18.5 to 8 weeks. As shown in Figure $3 C$, KO; $\mathrm{Tg}^{\mathrm{WT}}$ mice avoided lethality and reached adulthood, although the survival rate of $\mathrm{KO} ; \mathrm{Tg}^{\mathrm{WT}}$ mice was slightly less than in WT mice. The transgenic expression of $\mathrm{DINE}^{\mathrm{WT}}$ in motor neurons of $\mathrm{KO} ; \mathrm{Tg}^{\mathrm{WT}}$ mice disappeared at postnatal day 8 because the $H b 9$ promoter was used to express exogenous DINE protein (Fig. 3D). Even though DINE protein expression was shut down thereafter, the $\mathrm{KO} ; \mathrm{Tg}^{\mathrm{WT}}$ mouse developed and formed proper NMJs (Fig. 3E). 


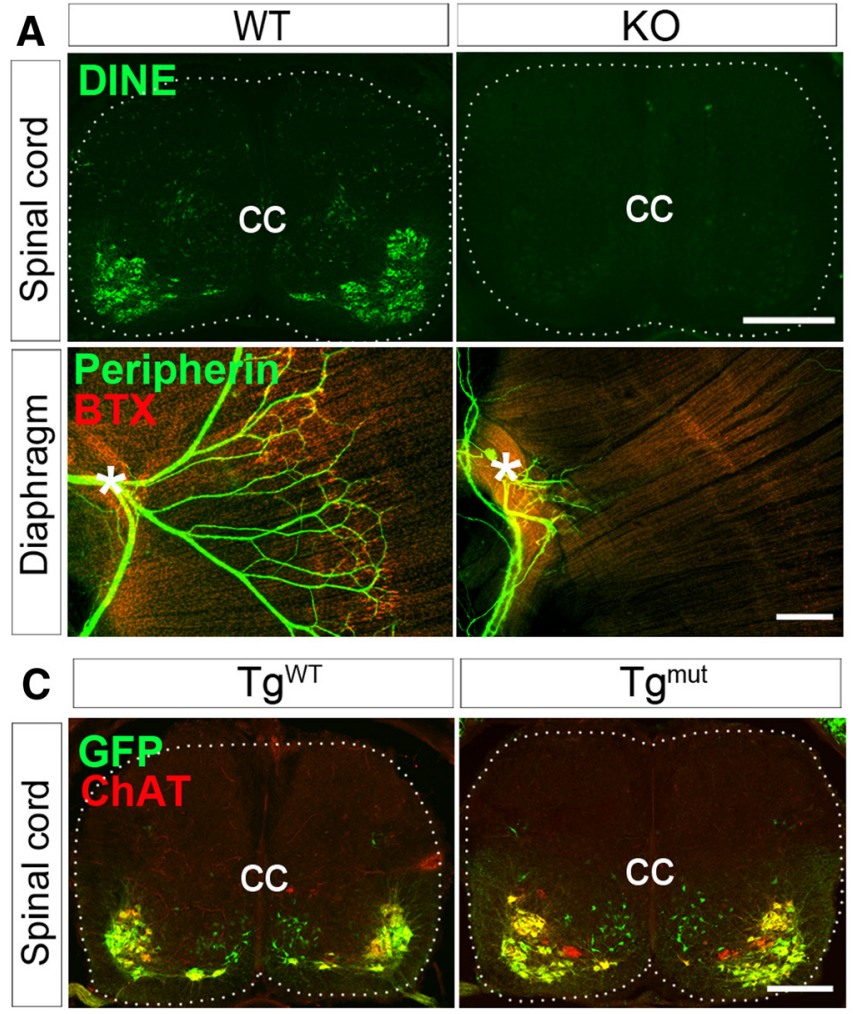

B Construct of $\operatorname{Tg}^{\mathrm{WT}}$ and $\mathrm{Tg}^{\text {mut }}$ mice
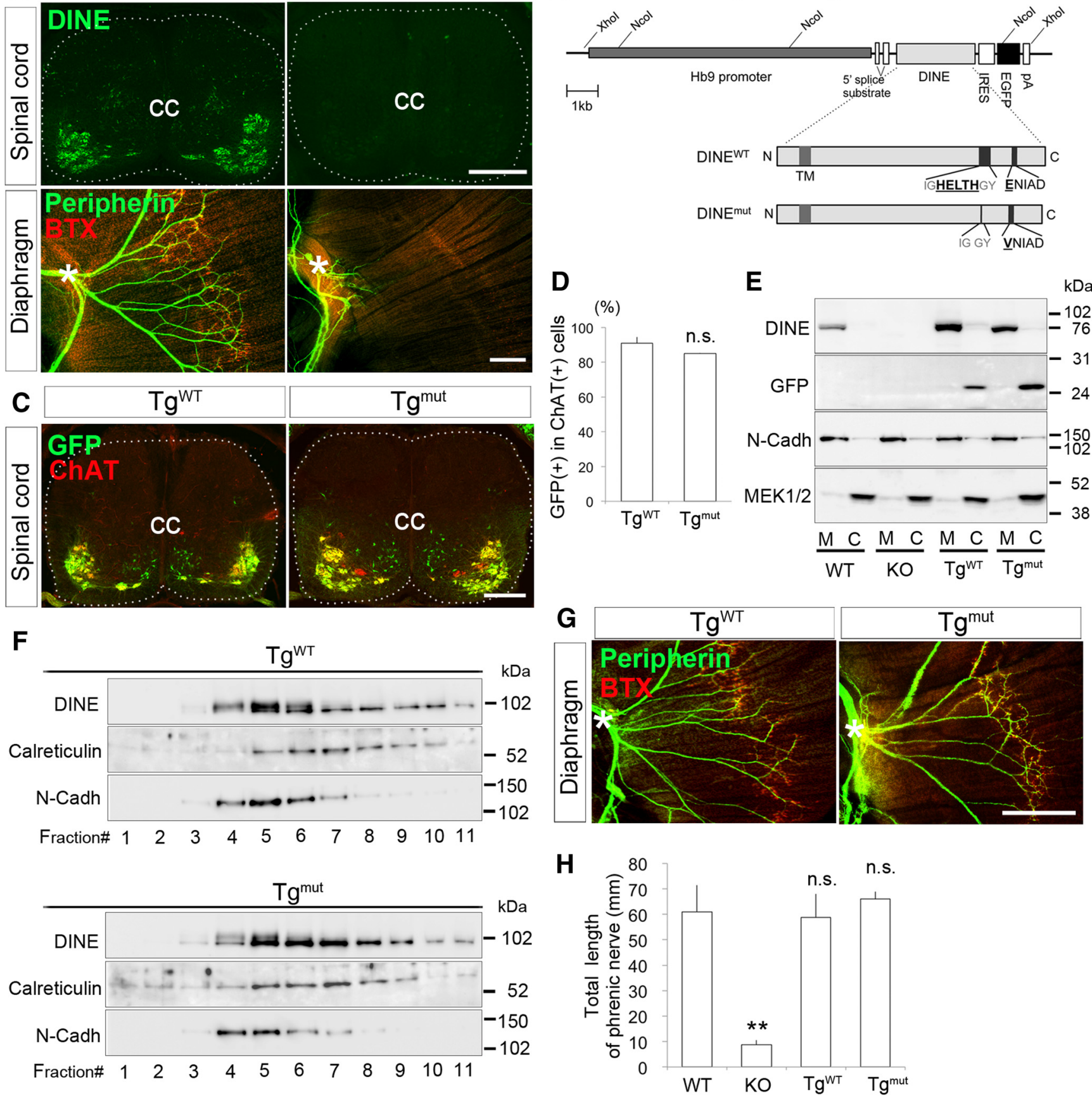

Figure 1. Generation of DINE ${ }^{W T}$ and DINE ${ }^{m u t}$ transgenic mice. $A$, Phenotype observed in spinal cord and diaphragm of DINE KO mice. Top column, DINE immunoreactivity observed in embryonic spinal cord (E17.5) in WT and DINE-deficient (K0) mice. Bottom column, Whole-mount preparation of diaphragm of WT and K0 embryos at E17.5, indicating the phrenic nerve arbor. Anti-peripherin antibody (green) and BTX (red) were used to identify nerves and synaptic structures of NMJ, respectively. No DINE-positive motor neurons are observed in the spinal cord of K0 mice, and the phrenic nerve arbor is strikingly poor in the diaphragm of KO mice. Asterisks indicate branching point. B, Constructs of $H b 9$ :DINE ${ }^{W T}\left(\operatorname{Tg}^{\mathrm{WT}}\right.$ ) and Hb9:DINE ${ }^{\text {mut }}$ (Tg ${ }^{\text {mut }}$ ) transgenic mice. Either CDNA encoding DINE ${ }^{W T}$ or DINE $E^{m u t}$ was inserted downstream of an $\sim 9 \mathrm{~kb} H b 9$ promoter, followed by IRES, EGFP, and polyA to express DINE and EGFP simultaneously in embryonic spinal motor neurons. In the DINE ${ }^{\text {mut }}$ construct, 5 amino acids (HELTH) were deleted and C-terminal Glu ${ }^{672}$ (E) was converted to Val (V). C, Coronal sections of the spinal cord at E17.5 of Tg ${ }^{\text {WT }}$ and Tg ${ }^{\text {mut }}$ mice. The sections were immunostained with anti-GFP (green) and anti-ChAT (red) antibodies. Both transgenic mice express GFP specifically in spinal motor neurons, and GFP intensity appears to be similar between Tg WT and $\mathrm{Tg}^{\text {mut }}$ mice. D, The ratio of GFP-positive cells in ChAT-positive motor neurons is similar between $\mathrm{Tg}^{\mathrm{WT}}$ and $\mathrm{Tg}{ }^{\text {mut }}$ mice. Almost all motor neurons in the cervical spinal cord at E17.5 express the transgene in both Tg mice. No statistically significant difference was seen. $\boldsymbol{E}$, Western blotting analysis of membrane (M) and cytosol (C) fractions using ventral spinal cord lysate from WT, K0, Tg ${ }^{\text {WT }}$, and $\mathrm{Tg}{ }^{\text {mut }}$ embryos at E13.5. N-Cadherin (N-Cadh) and MEK1/2 were used as positive controls for membrane and cytosol protein, respectively. $F$, Sucrose gradient fractionation using ventral spinal cord lysate from $\mathrm{Tg}{ }^{\mathrm{WT}}$, and Tg ${ }^{\text {mut }}$ embryos at E13.5. Calreticulin and N-Cadh were used as ER and plasma membrane markers, respectively. G, Whole-mount immunohistochemistry of diaphragm was performed using $\mathrm{E} 17.5 \mathrm{Tg}^{\mathrm{WT}}$ and $\mathrm{Tg}^{\mathrm{mut}}$ mice. Both $\mathrm{Tg}^{\mathrm{WT}}$ and $\mathrm{Tg}^{\text {mut }}$ mice exhibit similar arborization patterns of the phrenic nerve compared with WT mice. $\boldsymbol{H}$, Total length of the phrenic nerve, which is the sum of each branch length distal to the branching point ${ }^{*}$ in $G$ ), was measured using diaphragms from E17.5 WT, $\mathrm{KO}$, $\mathrm{Tg}^{\mathrm{WT}}$, and $\mathrm{Tg}{ }^{\text {mut }}$ mice. There are no significant differences between WT, $\mathrm{Tg}^{\mathrm{WT}}$, and $\mathrm{Tg}^{\text {mut }}$ mice. ${ }^{* *} p<0.01$. cc, Central canal. Scale bars: $A, C, 200 \mu \mathrm{m} ; G, 500 \mu \mathrm{m}$. n.s., Not significant. Error bars indicate SD. 

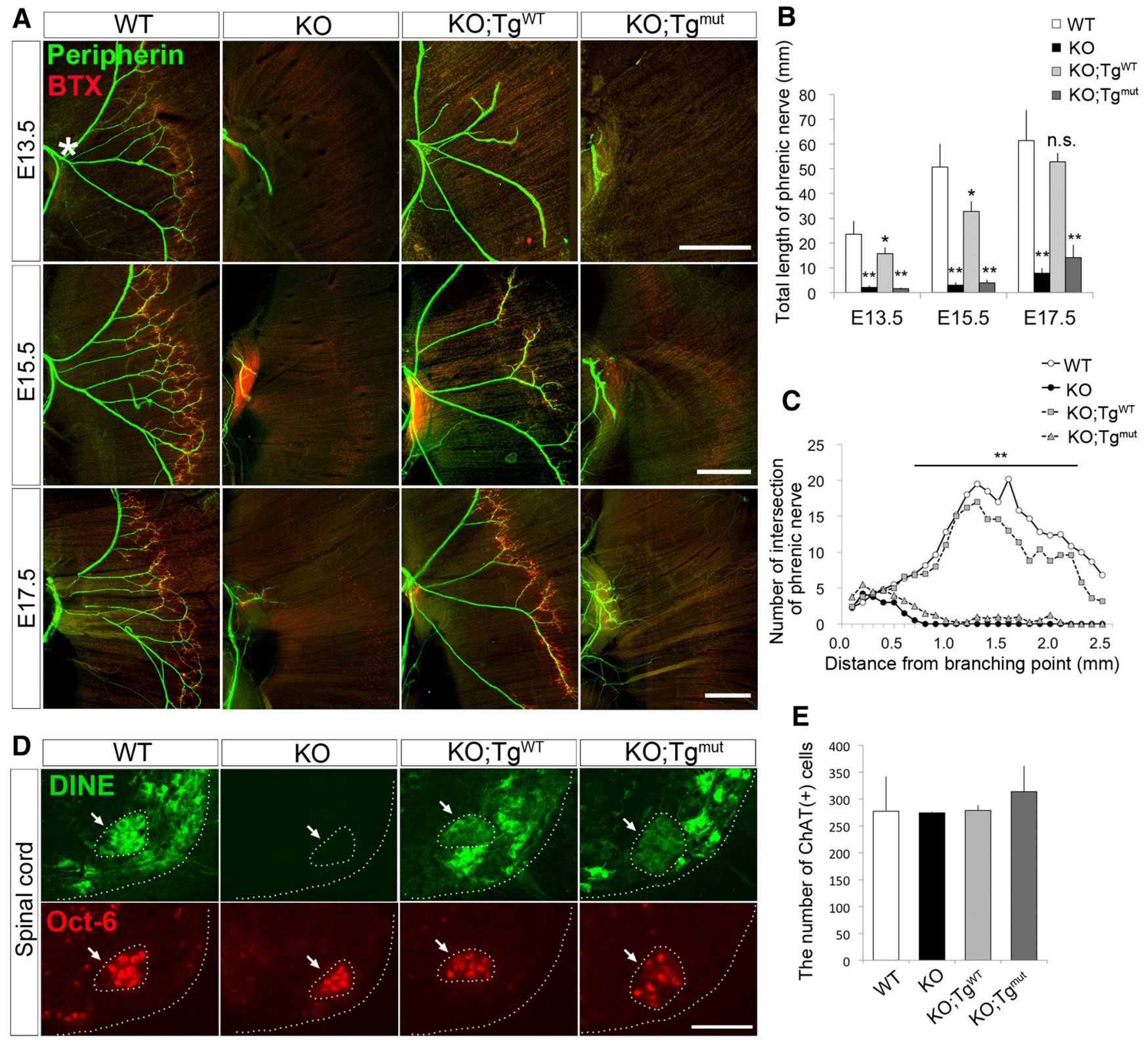

Figure 2. Exogenous DINE ${ }^{\mathrm{WT}}$ expression rescues aberrant arborization of phrenic nerves observed in $\mathrm{KO}$ mice, whereas DINE ${ }^{\text {mut }}$ expression fails to rescue the $\mathrm{KO}$ phenotype. $A$, Whole-mount immunohistochemistry reveals the phrenic nerve arbor in the diaphragm of WT, K0, K0; Tg ${ }^{\mathrm{WT}}$, and K0; $\mathrm{Tg}^{\text {mut }}$ mice at E13.5 (top), E15.5 (middle), and E17.5 (bottom) using anti-peripherin (green) antibody and BTX (red). The phrenic nerve of KO; $\mathrm{Tg}^{\mathrm{WT}}$ mice moderately recovers intramuscular arborization and forms a significant number of NMJs. However, the K0; Tg ${ }^{\text {mut }}$ mice are lacking arborization throughout all examined embryonic stages and exhibit a similar pattern to the DINE KO mouse. $\boldsymbol{B}$, Total length of phrenic nerve was determined as the sum of each branch length distal to the branching point $\left({ }^{*}\right.$ in $A$ ) at E13.5, E15.5, and E17.5. Although recovery of the total length appears slightly worse in E13.5 and E15.5 of K0; Tg WT mice, the nerve length is recovered in E17.5. Conversely, the K0; $\mathrm{Tg}^{\text {mut }}$ mouse exhibits no recovery at all stages. $t$ test compared with WT of equivalent embryonic day was performed. ${ }^{*} p<0.05 .{ }^{* *} p<0.01$. C, Sholl analysis of phrenic nerve arborization was performed using the diaphragm of E17.5 WT, $\mathrm{KO}, \mathrm{KO} ; \mathrm{Tg}^{\mathrm{WT}}$, and $\mathrm{K0}$; $\mathrm{Tg}^{\mathrm{mut}}$ mice. Nerve arbor complexity of $\mathrm{K0} ; \mathrm{Tg}{ }^{\mathrm{WT}}$ mice is as similar as that of WT mice, whereas it was significantly less in $\mathrm{K0} ; \mathrm{Tg}^{\text {mut }}$ mice. ${ }^{* *} \mathrm{p}<0.01$. D, Coronal sections of cervical spinal cord at E17.5 of WT, KO, K0; $\mathrm{Tg}^{\mathrm{WT}}$, and KO; $\mathrm{Tg}^{\text {mut }}$ mice were immunostained by anti-DINE (green) and anti-0ct-6 (red) antibodies for detection of either endogenous or exogenous DINE and phrenic motor neurons, respectively. Expression of exogenous DINE was detected in spinal motor neurons in K0;Tg ${ }^{\text {WT }}$ and $\mathrm{K} 0 ; \mathrm{Tg}^{\mathrm{mut}}$ mice, but the expression was slightly weak in phrenic motor neurons labeled with 0ct-6 (arrows) compared with endogenous DINE in WT mice. E, The number of ChAT-positive motor neurons in the cervical spinal cord was quantified, with no significant difference between WT, KO, K0; Tg ${ }^{\mathrm{WT}}$, and K0; $\mathrm{Tg}^{\text {mut }}$ mice at E17.5. cc, Central canal. Scale bars: $\boldsymbol{A}, 500 \mu \mathrm{m} ; \boldsymbol{D}, 200 \mu \mathrm{m}$. n.S., Not significant. Error bars indicate SD.

\section{Proper innervation of other skeletal muscles was impaired in} KO; Tg $^{\text {mut }}$ mice

We confirmed that DINE protease activity was required for nerve arborization and NMJ formation using another motor nerve. We performed whole-mount immunohistochemistry on the LD of E15.5 and E17.5 embryos and visualized the thoracodorsal nerve terminal projecting to the $\mathrm{LD}$. Results showed that the $\mathrm{KO}$; $\mathrm{Tg}^{\mathrm{WT}}$ nerve terminal arborized and was sufficiently elongated to form the NMJ with no obvious difference from WT mice (Fig. 4A). However, the $\mathrm{KO} ; \mathrm{Tg}^{\text {mut }}$ mice exhibited several axons that elongated from the nerve trunk to form the NMJ but did not properly arborize, which was a similar phenotype to the $\mathrm{KO}$ mice at E15.5 and E17.5. To quantify these phenotypes, we measured the total length of thoracodorsal nerves and counted the points where nerve branches subdivided or merged (termed as the cross point). The length and number of cross points in $\mathrm{KO}$; $\mathrm{Tg}^{\mathrm{WT}}$ mice were 


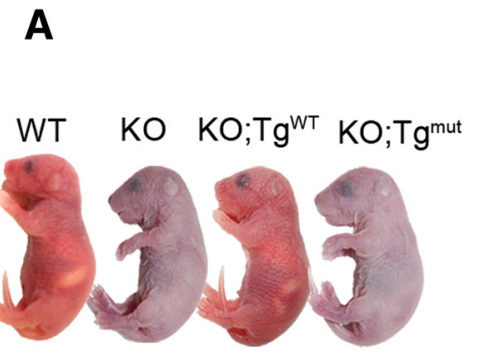

B

\begin{tabular}{|c|c|c|c|c|c|c|c|c|c|c|c|c|}
\hline \multirow[b]{2}{*}{ Age } & \multicolumn{6}{|c|}{ Animal number } & \multicolumn{6}{|c|}{ Surviving pups (\%) } \\
\hline & Total & WT & Het & $\mathrm{KO}$ & WT & Het $\mathrm{KO}$ & WT & Het & $\mathrm{KO}$ & WT & Het & $\mathrm{KO}$ \\
\hline \multirow{4}{*}{$\begin{array}{l}\text { E18.5 } \\
\text { P0 }\end{array}$} & & & & & & $\mathrm{Tg}^{\mathrm{WT}}$ & & & & & $\mathrm{Tg}^{\mathrm{WT}}$ & \\
\hline & & 14 & 4 & 11 & 15 & 32 & - & - & - & & - & - \\
\hline & 1 & 17 & 3 & 19 & 26 & 40 & 88.2 & 96.8 & 0.0 & 00.0 & 100.0 & 94.4 \\
\hline & & & \multicolumn{4}{|r|}{ 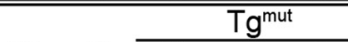 } & & & & \multicolumn{3}{|c|}{ 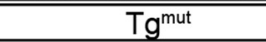 } \\
\hline & 90 & 9 & 23 & 11 & 11 & 27 & - & - & - & & & - \\
\hline & 42 & 6 & 7 & 5 & 5 & 13 & 100.0 & 100.0 & 0.0 & 100.0 & $00 .($ & 0.0 \\
\hline
\end{tabular}
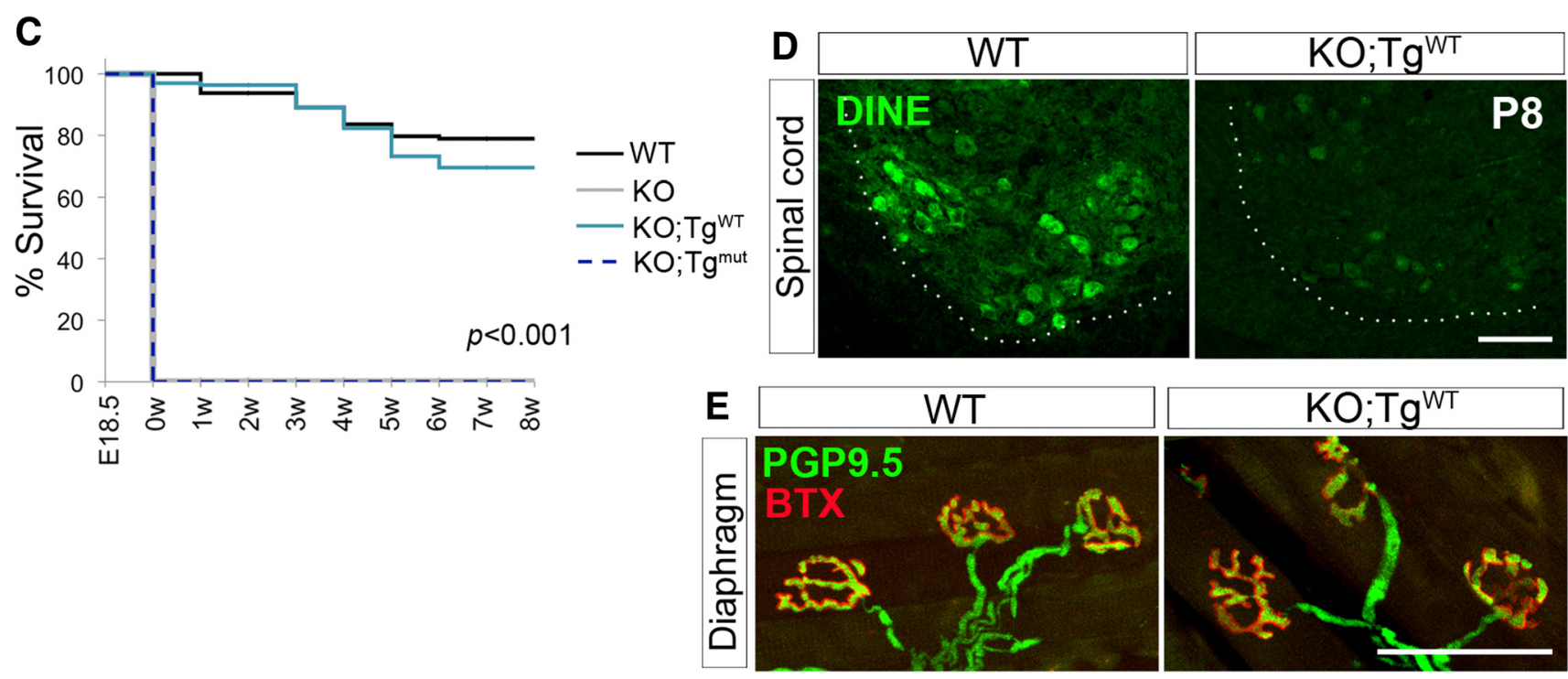

Figure 3. Embryonic rescue of DINE expression is sufficient for KO; $\mathrm{Tg}^{\mathrm{WT}}$ mice to survive and develop normally. $A$, The appearance of $\mathrm{WT}, \mathrm{KO}, \mathrm{KO} ; \mathrm{Tg}^{\mathrm{WT}}$, and $\mathrm{K0} ; \mathrm{Tg}^{\text {mut }}$ mice at PO. WT and K0; ${ }^{\mathrm{WT}}$ mice were viable, whereas $\mathrm{KO}$ and $\mathrm{KO} ; \mathrm{Tg}{ }^{\text {mut }}$ mice exhibited cyanosis and died immediately after birth. $\boldsymbol{B}$, The table shows the number of littermates from each genotype at E18.5 and P0, as well as the proportion of surviving pups to total pups when crossing with mice carrying the DINE $E^{W T}$ or DINE ${ }^{m u t}$ transgene, respectively. Before birth, all genotypes were observed at a Mendelian ratio, but $\mathrm{KO}$ and $\mathrm{KO} ; \mathrm{Tg}^{\text {mut }}$ pups died immediately after birth. C, Kaplan-Meier survival curve of WT, K0, KO; $\mathrm{Tg}^{\mathrm{WT}}$, and K0; $\mathrm{Tg}^{\text {mut }}$ mice from E18.5 to 8 weeks were analyzed by log-rank tests ( $\left.p<0.001\right)$. D, The immunohistochemical staining of DINE in spinal motor neurons of WT and K0; Tg ${ }^{\mathrm{WT}}$ at P8. $E$, NMJs in the diaphragm from adult WT and K0; Tg ${ }^{\mathrm{WT}}$ mice were immunostained using antibodies specific for PGP9.5 (green) and BTX (red). Scale bars: D, $200 \mu \mathrm{m} ; \boldsymbol{E}, 50 \mu \mathrm{m}$.

similar to WT mice but were significantly reduced in the KO; $\mathrm{Tg}^{\text {mut }}$ mice (Fig. $4 B, C$ ). These results suggested that proper DINE protease activity is critical for intramuscular arborization and NMJ formation of the motor nerve terminal during development.

\section{A single mutation of DINE failed to rescue abnormalities in DINE KO mice}

To further assess the significance of the protease activity of DINE in the motor nerve arborization, we generated another mutant DINE (DINE ${ }^{E 613 V}$ ) transgenic mouse (Tg $\left.{ }^{\mathrm{E} 613 \mathrm{~V}}\right)$ (Fig. $\left.5 \mathrm{~A}\right)$, which carried a single point mutation at the catalytic HELTH motif; we used this point mutation because previous in vitro studies showed that proteolytic activities of NEP or ECE were abolished by a single point mutation of glutamate residue in the catalytic HExxH motif (Devault et al., 1988a; Shimada et al., 1996). $\mathrm{Tg}^{\mathrm{E} 613 \mathrm{~V}}$ mice expressed enough amounts of exogenous GFP in ChAT-positive motor neurons in developing spinal cord (Fig. $5 B)$. The resulting mouse strain from crossing a DINE KO mouse with $\mathrm{Tg}^{\mathrm{E} 613 \mathrm{~V}}$ mouse $\left(\mathrm{KO} ; \mathrm{Tg}^{\mathrm{E} 613 \mathrm{~V}}\right)$ expressed similar amounts of exogenous DINE to $\mathrm{KO} ; \mathrm{Tg}^{\mathrm{WT}}$ mice (Fig. $5 \mathrm{C}$ ). The phrenic nerve in diaphragm of $\mathrm{KO}$; $\mathrm{Tg}^{\mathrm{E} 613 \mathrm{~V}}$ mouse showed aberrant arborization in similar manner to that of KO mouse (Fig. 5D,E). The thoracodorsal nerve terminal in the LD muscle showed abnormal arborization in $\mathrm{KO} ; \mathrm{Tg}^{\mathrm{E} 613 \mathrm{~V}}$ mouse, although the abnormality was milder in $\mathrm{KO} ; \mathrm{Tg}^{\mathrm{E} 613 \mathrm{~V}}$ mouse than that in the $\mathrm{KO}$ mouse (Fig.
$5 D, F)$. These findings suggest that the protease activity of DINE is critical for motor nerve arborization during development, but a single point mutation in DINE may be insufficient to completely inactivate protease activity in vivo.

\section{Axonal DINE deficiency affects interactions between axons and immature Schwann cells}

We next analyzed the detailed morphological appearance of phrenic nerves between WT and KO mice. Toluidine bluestained semithin diaphragm sections from E17.5 embryos showed that phrenic nerves in WT mice reached the diaphragm and then extended axon tips into the middle layer of the diaphragm thickness where connective tissue space was present (Fig. 6A). In the KO mice, the primary trunk similarly reached the muscle. However, the phrenic nerves lost the elongation direction and eventually stopped. We also found that morphological appearance of cells along the axons was different between WT and KO mice. In the WT mice, spindleshaped cells were aligned along the axon, whereas numerous round-shaped cells were observed along DINE-deficient axons in the KO mice (Fig. 6A). These cells were assumed to be immature Schwann cells. Previous work has presumed that axons are initially guided to the target muscle, independent of the migration of SCPs (Lin et al., 2000). However, once axons arrive at the muscle, axons and SCPs communicate with each other, which promotes the transition from SCPs to immature 

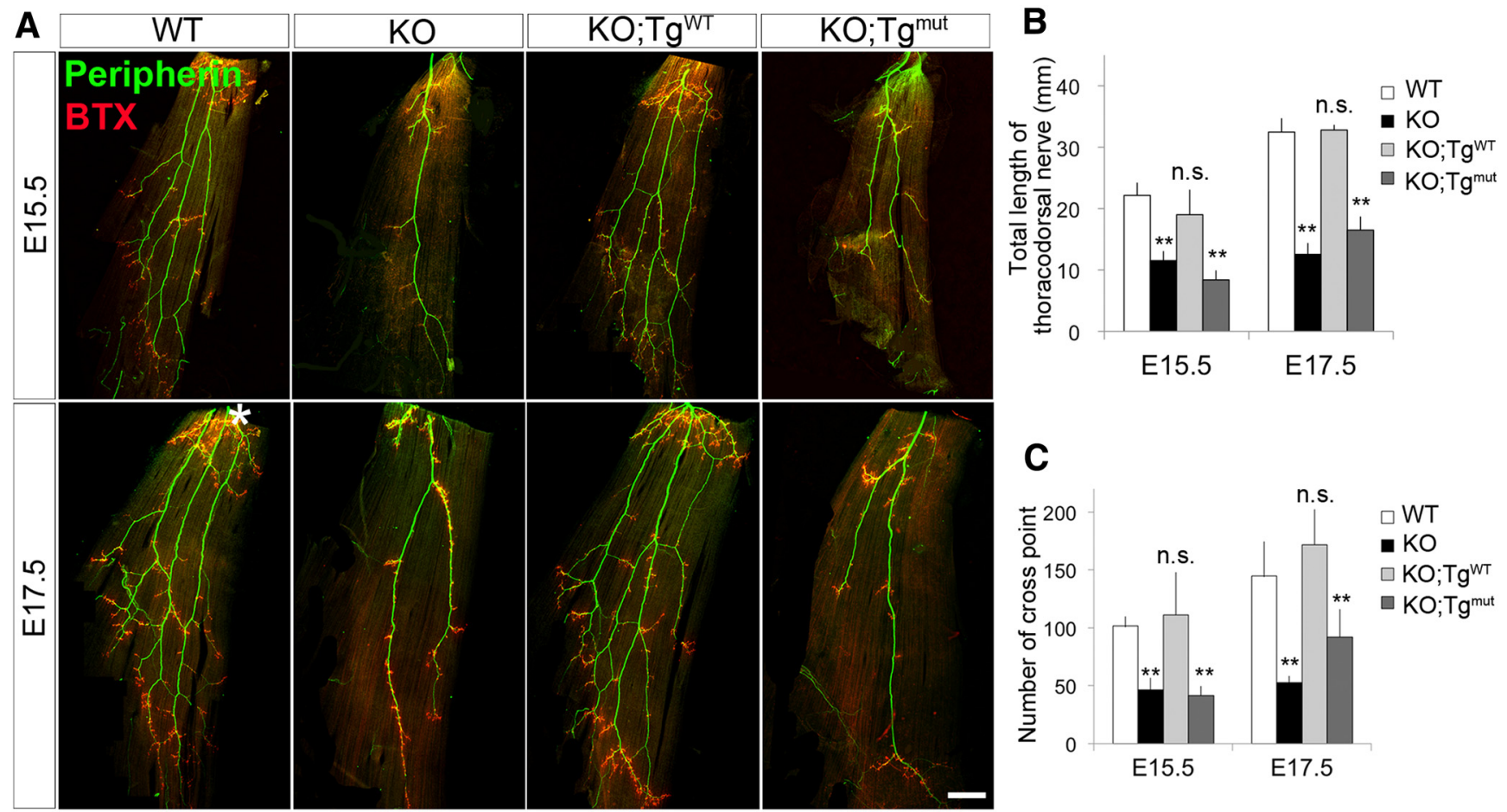

Figure 4. Arborization of the thoracodorsal nerve in the LD muscle in $K 0$ mouse is rescued by exogenous DINE ${ }^{\text {WT }}$ expression, but not by DINE ${ }^{\text {mut }}$ expression. $A$, Whole-mount immunohistochemistry using the LD of WT, K0, K0; $\mathrm{Tg}^{\mathrm{WT}}$, and K0; $\mathrm{Tg}^{\text {mut }}$ mice at E15.5 (top) and E17.5 (bottom). Thoracodorsal nerve and postsynaptic structure of NMJ were immunostained using anti-peripherin antibody (green) and BTX (red), respectively. Nerve terminal of K0; Tg ${ }^{\mathrm{WT}}$ mice shows similar terminal arborization patterns to WT mice, whereas K0; Tg ${ }^{\text {mut }}$ mice exhibit much less secondary, tertiary, and quaternary branches compared with KO mice. $\boldsymbol{B}$, Total length of the thoracodorsal nerve was determined as the sum of each branch length distal to the branching point $\left({ }^{*}\right.$ in $\left.\boldsymbol{A}\right)$ at E15.5 and E17.5. There is no significant difference in nerve length between WT and K0; Tg ${ }^{\mathrm{WT}}$ mice, whereas nerve lengths of $\mathrm{KO}$ and $\mathrm{K0} ; \mathrm{Tg}^{\mathrm{mut}}$ mice significantly decrease compared with WT mice. ${ }^{* *} p<0.01$. C, The cross point where each branch divides or merges was quantified in the LD muscle of WT, K0, KO; $\mathrm{Tg}^{\mathrm{WT}}$, and K0; $\mathrm{Tg}^{\text {mut }}$ mice at E15.5 and E17.5. Similar levels of cross points are observed in WT and $\mathrm{KO} ; \mathrm{Tg}^{\mathrm{WT}}$ mice, with significantly less in $\mathrm{KO}$ and $\mathrm{KO} ; \mathrm{Tg}^{\text {mut }}$ mice. ${ }^{* *} p<0.01$. Scale bar: $A, 500 \mu \mathrm{m}$. n.S., Not significant. Error bars indicate SD.

Schwann cells, as well as neurite extension and myelination after birth. Because DINE was not expressed in Schwann cells at any developmental stage, we hypothesized that axonal DINE deficiency caused abnormal interactions between axons and immature Schwann cells, as well as abnormal differentiation of immature Schwann cells, which led to aberrant nerve terminal arborization of DINE KO mice. Immunohistochemical staining of embryonic diaphragm sections at E17.5 showed that p75-positive immature Schwann cells existed around phrenic motor axons in WT and $\mathrm{KO}$ mice (Fig. 6B), suggesting that SCPs had successfully migrated along the axon during the early developmental stage. However, consistent with results from semithin sections, we found that morphological appearance and alignment of these immature Schwann cells were different between WT and KO mice. In the WT mice, alignment of immature Schwann cells was well organized; DAPI-stained nuclei of Schwann cells were flat and aligned along the axon in the same direction. However, nuclei of immature Schwann cells in the $\mathrm{KO}$ mice appeared round and more widely spread from the axon-rich region. These results suggest that DINE deficiency affects proliferation or differentiation of immature Schwann cells.

\section{Axonal DINE deficiency affects immature Schwann cells during late embryonic development}

We then examined the number of SCPs or immature Schwann cells along the axons between WT and DINE KO mice at E13.5 and E16.5. The number of DAPI-stained nuclei per $1 \times 10^{4}$ $\mu \mathrm{m}^{2}$ of spinal nerve sections did not change between WT and $\mathrm{KO}$ mice at both ages (Fig. 7A). To further ensure the prolif- eration status of SCPs/immature Schwann cells, pregnant mice were intraperitoneally injected with BrdU and then killed $1 \mathrm{~h}$ later for proliferation analysis. Proliferation was examined using the ratio of BrdU-positive nuclei to total nuclei counterstained with DAPI (Fig. $7 B$ ). Both WT and KO mice had $\sim 13 \%-16 \%$ BrdU-positive cells in the ventral root of spinal motor nerves at both ages, suggesting that DINE deficiency does not affect proliferation of the nerve cells (Fig. $7 B, C$ ). In addition, immunohistochemical analysis revealed that Sox2, Sox10, and ErbB3 were expressed in embryonic spinal nerves from WT and KO mice in a similar manner (data not shown); furthermore, SCPs/immature Schwann cells in embryonic sciatic nerves expressed cell cycle related-genes similarly between WT and KO mice (Fig. 7D). These data suggested that SCPs and/or immature Schwann cells along axons proliferate similarly in WT and $\mathrm{KO}$ mice.

We next examined the differentiation status of immature Schwann cells in spinal nerves of WT and KO mice. The SCP/ immature Schwann cells require coordinated changes in molecular expression for differentiation (Jessen and Mirsky, 2005). Although the detailed molecular mechanisms remain poorly understood, some factors have been implicated in the control of early Schwann cell development (Jessen and Mirsky, 2005). We compared mRNA expression of those molecules in E18.5 embryonic sciatic nerves of WT and KO mice (Fig. 7E). Of the genes examined, mRNA expression of Oct-6, a transcription factor that activates promyelin pathways and initiates myelinations in immature Schwann cells, was significantly less in nerves from KO mice than in WT mice. In situ hybridization and immunohistochemical analysis further 
A Construct of $\mathrm{Tg}^{\mathrm{E} 613 \mathrm{~V}}$ mice

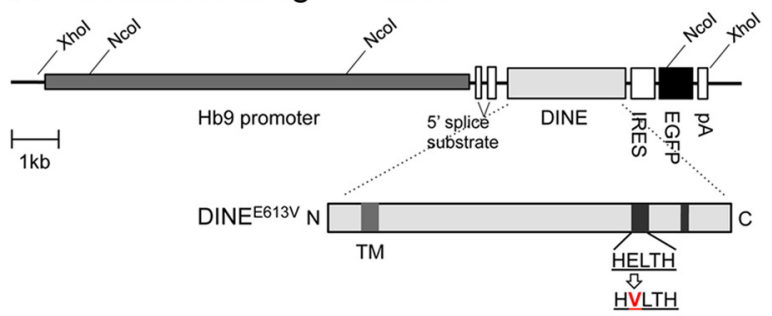

B

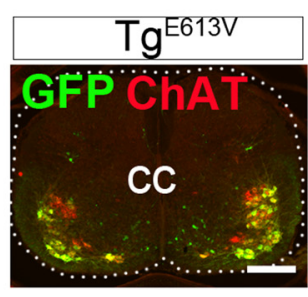

C

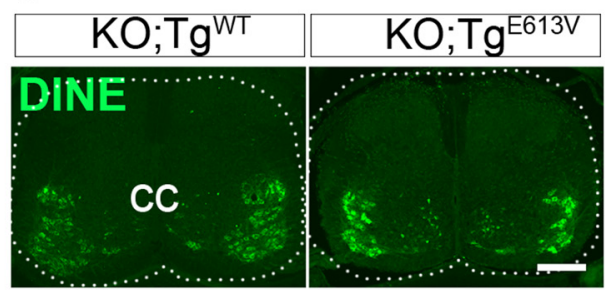

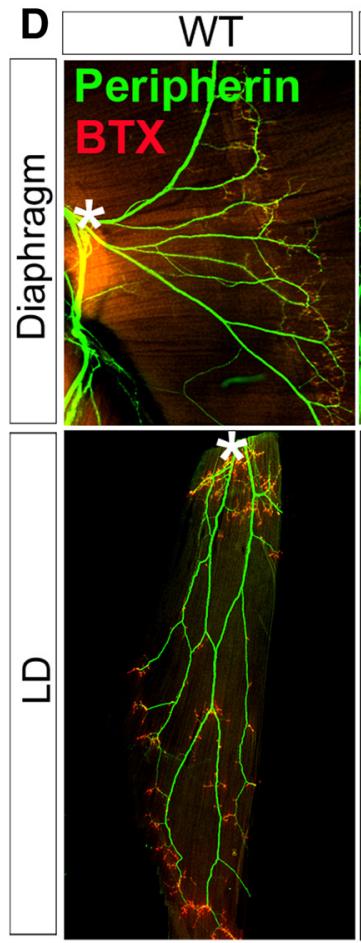
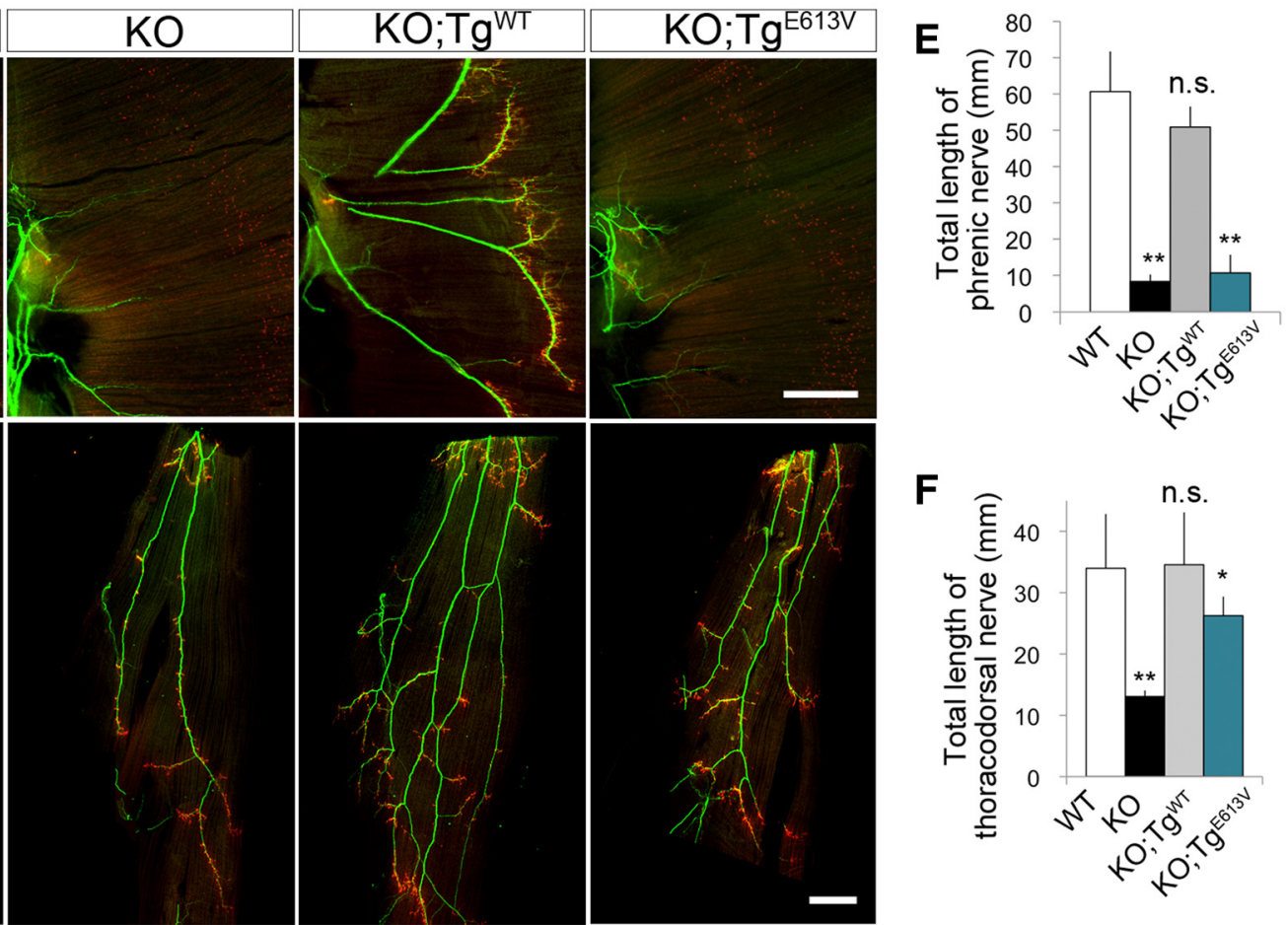

Figure 5. Point-mutated DINE ${ }^{E 613 V}$ fails to rescue the DINEKO phenotype. $A$, Constructs of $H b 9: D I N E^{E 613 V}\left(\operatorname{Tg}^{E 613 V}\right)$ transgenic mice. CDNA encoding DINE $E^{E 613 V}$ was inserted downstream of an $\sim 9$ $\mathrm{kb} \mathrm{Hb} 9$ promoter, followed by IRES, EGFP, and polyA to express DINE and EGFP simultaneously in embryonic spinal motor neurons. In the DINE ${ }^{\text {E613V }}$ construct, Glu ${ }^{613}$ (E) was converted to Val (V). $\boldsymbol{B}$, Coronal section of the spinal cord at E17.5 of Tg ${ }^{\text {E613V }}$ mouse was immunostained with anti-GFP (green) and anti-ChAT (red) antibodies. Most of ChAT-positive motor neurons expressed exogenous GFP specifically in spinal motor neurons. C, Coronal sections of the spinal cord at E17.5 of K0; $\mathrm{Tg}^{\mathrm{WT}}$ and $\mathrm{K0} ; \mathrm{Tg}{ }^{\mathrm{E} 613 \mathrm{~V}}$ mice were immunostained with anti-DINE antibody (green). D, Whole-mount immunohistochemistry reveals the phrenic nerve arbor in the diaphragm (top) and the thoracodorsal nerve arbor in LD (bottom) of WT, K0, K0; $\mathrm{Tg}^{\mathrm{WT}}$, and K0; $\mathrm{Tg}^{\mathrm{E}}{ }^{613 \mathrm{~V}}$ mice at E17.5 using anti-peripherin (green) antibody and BTX (red). $\boldsymbol{E}, \boldsymbol{F}$, Total length of phrenic nerve $(\boldsymbol{E})$ or thoracodorsal nerve $(\boldsymbol{F})$ was determined as the sum of each branch length distal to the branching point ${ }^{*}$ in $\boldsymbol{D})$ at E17.5. ${ }^{* *} p<0.01 .{ }^{*} p<0.1$. cc, Central canal. Scale bars: $\boldsymbol{B}, \boldsymbol{C}, 200 \mu \mathrm{m} ; \boldsymbol{D}, 500 \mu \mathrm{m}$. n.s., Not significant. Error bars indicate SD.

confirmed decreased Oct-6 mRNA and protein expression in the ventral root of spinal nerves in $\mathrm{KO}$ embryos compared with WT embryos (Fig. $7 F$ ). Collectively, DINE deficiency in axons did not affect proliferation of SCPs/immature Schwann cells, but Oct- 6 expression was altered, suggesting that the differentiation process of SCPs/immature Schwann cells may be impaired by DINE deficiency in axons.

\section{DINE deficiency alters interactions between axons and}

\section{Schwann cells in vitro}

Finally, we investigated the interaction between axons and Schwann cells using primary motor neuron cultures prepared from the spinal ventral column of E12.5 embryos and Schwann cell cultures. We initially compared neurite elongation activity of cultured motor neurons between WT and KO mice. As shown in Figure $8 A, B$, there was no significant difference in neurite elongation between WT and KO mice. We next added separately cultured rat Schwann cells to WT or KO motor neuron cultures and measured neurite length. The addition of Schwann cells had no significant difference in elongation between WT and KO neurites (Fig. 8B). We then examined whether
DINE deficiency affected contact and alignment of Schwann cells with axons. When normal Schwann cells are added to motor neuron cultures, Schwann cell processes generally make contact with axons, associate and align to them, and eventually proliferate in response to axonal signals. Consistent with this, we observed that Schwann cells extended their processes along the neurites and formed a bipolar morphology to establish axonal contacts in cultures with WT motor neurons (Fig. 8C). We termed the bipolar-shaped and axonassociated Schwann cells as "aligned Schwann cells." In contrast to WT, cultures using KO motor neurons showed reduced numbers of aligned Schwann cells (Fig. 8C), and quantification analysis revealed a significantly decreased proportion of aligned Schwann cells along KO neurites (Fig. 8D). We further examined whether axonal DINE protease activity was involved in the change in Schwann cell morphology using motor neurons from $\mathrm{KO} ; \mathrm{Tg}^{\mathrm{WT}}$ and $\mathrm{KO}$; $\mathrm{Tg}^{\text {mut }}$ mice. From the results obtained in Figure 5, we used the DINE ${ }^{\text {mut }} \mathrm{Tg}$ with a deletion in the HELTH active motif in vitro study to ensure complete loss of protease activity. The proportion of aligned Schwann cells in cocultures using $\mathrm{KO} ; \mathrm{Tg}^{\mathrm{WT}}$ mice was not different from WT mice. However, in cocultures using $\mathrm{KO} ; \mathrm{Tg}^{\text {mut }}$ mice, we observed a 
A

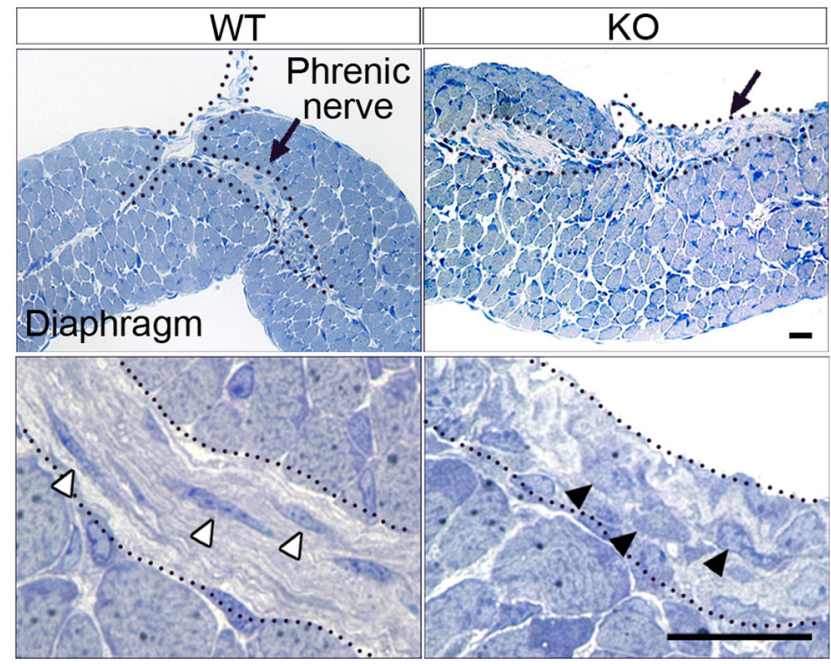

B
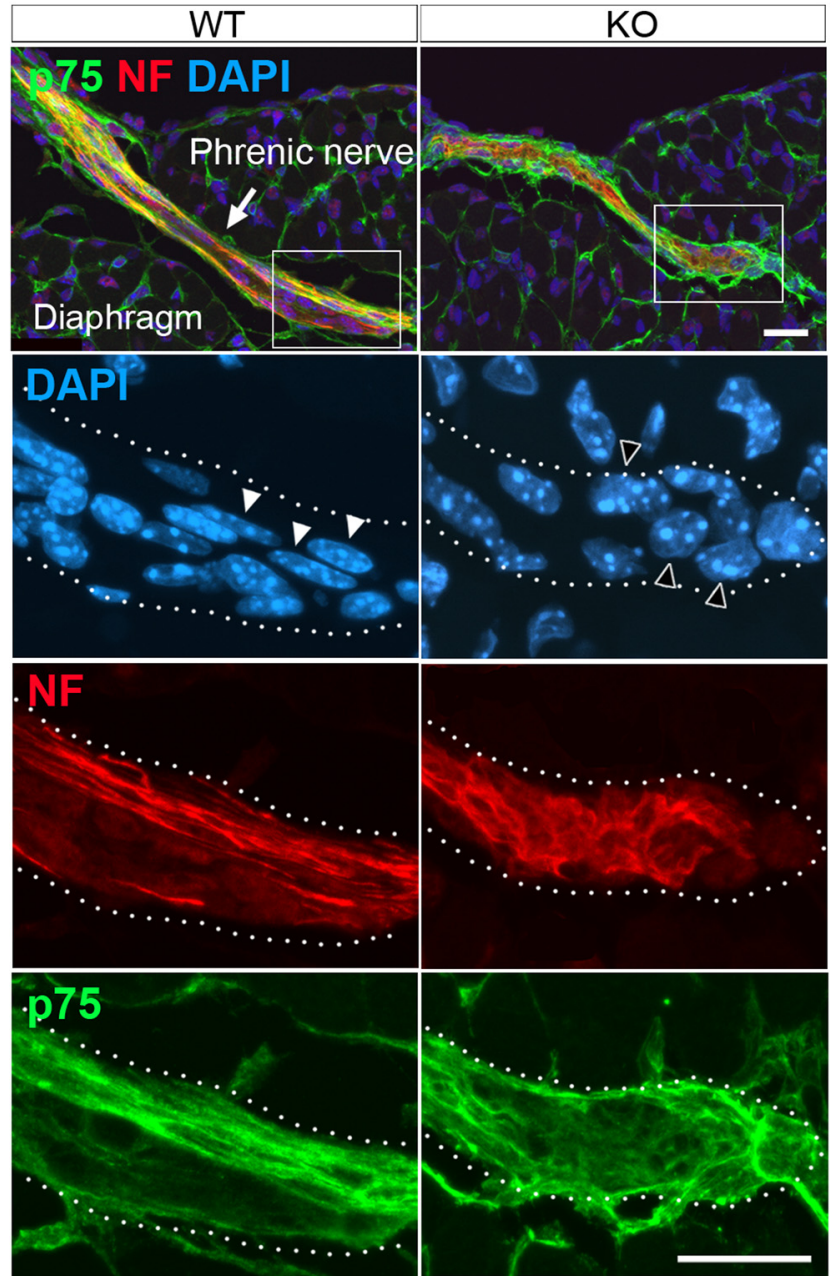

Figure 6. DINE deficiency causes morphological alterations in immature Schwann cells along the phrenic nerve. $\boldsymbol{A}$, Semithin sections of the sagittal diaphragm at E17.5 of WT and K0 mice stained with toluidine blue (top) and higher magnification of toluidine blue-stained sections of diaphragm (bottom). Dashed line indicates border between phrenic nerve and muscle. Phrenic nerve of WT mouse has spindle-shaped cells (white arrowheads), whereas the cells in the $\mathrm{KO}$ mouse are rounded (black arrowheads). $\boldsymbol{B}$, Sagittal sections of paraffin-embedded diaphragm at E17.5 from WT and K0 mice immunostained with anti-p75 (green) and antineurofilament (NF, red) antibodies and DAPI (blue). Bottom three rows represent higher magnification of white frame in the top. Most DAPI-stained nuclei possibly indicate decreased proportion of aligned Schwann cells compared with WT mice (Fig. $8 D$ ). These data suggested that axonal DINE protease activity influenced interactions of Schwann cells with axons, rather than axonal elongation.

\section{Discussion}

The present study attempted to address the question of whether the putative proteolytic domain of DINE is necessary to form proper nerve arborization in skeletal muscle and subsequent NMJ formation. Other proteases, such as ADAM, whose primary structure is also a membrane-bound metalloprotease, function as adhesion molecules, not as proteases in the formation of the NMJ (Yumoto et al., 2008). The present rescue experiment used transgenic mice that express DINE with a mutation in the putative protease domain. Results showed that the DINE protease domain is required for intramuscular arborization of motor nerves and subsequent NMJ formation during embryonic development. Further evidence showed that the DINE protease domain mutation suppresses differentiation of immature Schwann cells, as well as interactions between axons and immature Schwann cells.

In DINE KO mice, a significant loss of intramuscular arborization of the phrenic motor nerve in the diaphragm has been observed, although the trajectory of the phrenic nerve from the cervical spinal cord to the diaphragm is normal (Nagata et al., 2010). There was no significant phenotypic difference in phrenic nerve arborization in the diaphragm between WT, DINE het, and DINE-overexpressing ( $\mathrm{Tg}^{\mathrm{WT}}$ or Tg ${ }^{\text {mut }}$ ) mice. DINE protein expression levels did not seem to affect the phenotype in the present study. These findings suggest that proteolytic activity of DINE may be the critical factor, rather than the amount of protein. Despite the wide permissive amounts of DINE protein, phrenic nerve arborization was not completely rescued in the KO; $\mathrm{Tg}$ WT mice. This is likely due to significantly lower exogenous DINE protein expression in the phrenic motor pool of $\mathrm{KO} ; \mathrm{Tg}^{\mathrm{WT}}$ mice compared with that of DINE het mice.

Intriguingly, embryonic rescue of DINE deficiency in spinal motor neurons was sufficient for the mice to avoid lethality and develop normally after birth, even without DINE protein expression after postnatal $8 \mathrm{~d}$. This suggests that DINE expression during the embryonic period is critical for motor neurons to properly innervate and that other proteins are not able to compensate for DINE deficiency during embryonic development. After the period, DINE could have additional functions in motor neurons because DINE is continuously expressed in adult spinal motor neuron. The mechanisms involved in the regulation of DINE expression during development remain poorly understood. Considering the phenotypic similarity of developing phrenic nerves in the Hox5-deficient mice (Philippidou et al., 2012) and DINE KO mice, Hox 5 might be a potential regulator of DINE expression during development.

In the present study, we have found that proteolytic activity of DINE is important for motor nerve arborization using the two types of mutant DINE transgenic mouse strains, which encoded a deleted HELTH motif and a mutated Glu ${ }^{672}$ or a single pointmutated $\mathrm{Glu}^{613}$. After crossing the DINE KO with the both mutant $\mathrm{Tg}$ mice, the resulting mouse strains exhibited aberrant arborization of the phrenic nerve. However, $\mathrm{KO} ; \mathrm{Tg}^{\mathrm{E} 613 \mathrm{~V}}$ showed

p75-positive immature Schwann cells. The shapes of DAPI-stained nuclei are flat in the WT mouse (white arrowheads) but rounded in the K0 mouse (open arrowheads). Dashed line indicates outline of phrenic nerve. Scale bars: $\boldsymbol{A}, \boldsymbol{B}, 20 \mu \mathrm{m}$. 

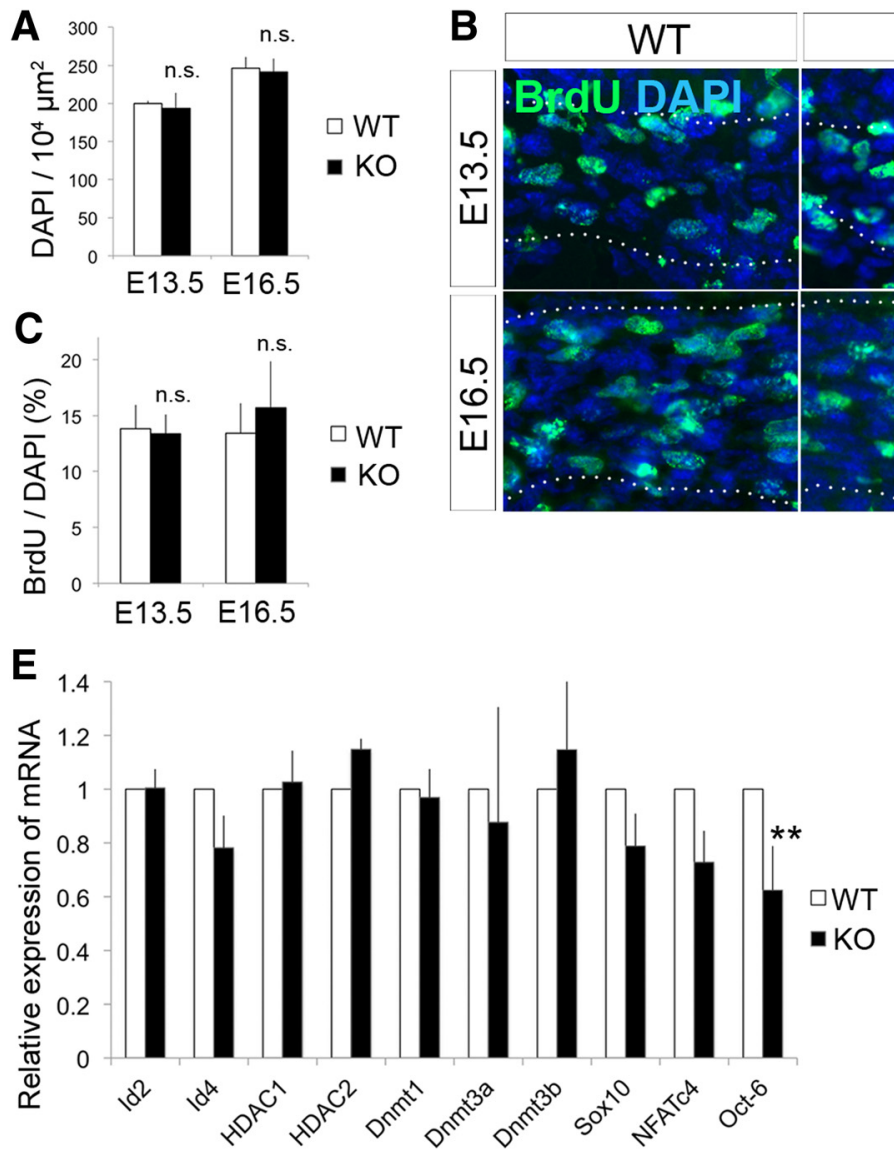
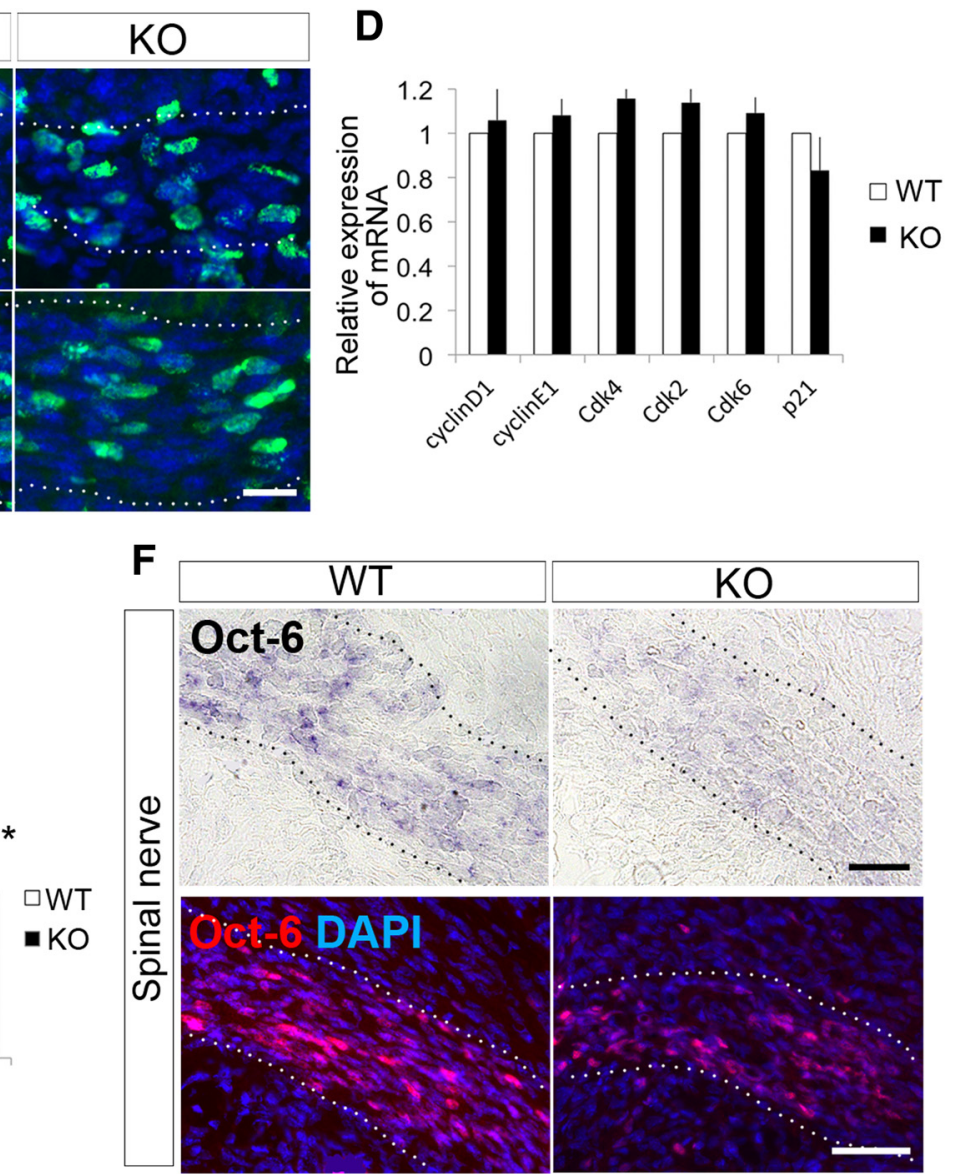

Figure 7. DINE deficiency alters differentiation status of immature Schwann cells, but not proliferation. $A$, The number of DAPI-stained nuclei per $10^{4} \mu \mathrm{m}^{2}$ in cervical spinal ventral root sections of WT and KO mice at E13.5 and E16.5 are shown. There is no significant difference in the number of stained nuclei between WT and KO mice. $\boldsymbol{B}$, BrdU was intraperitoneally injected into pregnant mice and was incorporated in proliferating cells of E13.5 and E16.5 embryos. Longitudinal sections of spinal ventral root at the cervical level were immunostained by anti-BrdU antibody (green) and DAPI (blue). C, The percentages of BrdU-positive nuclei in DAPI-stained nuclei of WT and KO mice. There is no significant difference between WT and K0 mice with regard to the number of BrdU-positive proliferating cells in the spinal nerve. D, Expression of cell cycle-related genes in sciatic nerves of WT and K0 mice at E18.5. Actin expression is served as a reference. Data are shown as a fold induction compared with mRNA expression in WT mice. All genes show no significant difference in mRNA expression between WT and KO mice. $\boldsymbol{E}$, Quantified expression levels of genes associated with differentiation of immature Schwann cells in embryonic sciatic nerve of WT and K0 at E18.5. Data are shown as a fold induction compared with expression in WT mice. Expression of Oct- 6 is significantly decreased in the sciatic nerve of KO embryos. ** $p<0.01$. $F$, In situ hybridization using DIG-labeled RNA probe confirms increased expression of $0 c t-6 \mathrm{mRNA}$ in WT mice compared with KO mice (top); immunohistochemistry using anti-0ct-6 antibody (red) and DAPI (blue) confirms considerably induced 0ct-6 expression in WT mice at E17 compared with K0 mice (bottom). Scale bars: $\boldsymbol{B}, 20 \mu \mathrm{m} ; \boldsymbol{F}, 100 \mu \mathrm{m}$. n.s., Not significant. Error bars indicate SD.

milder abnormalities of the thoracodorsal nerve than $\mathrm{KO}$ and $\mathrm{KO} ; \mathrm{Tg}^{\text {mut }}$. We therefore suspected that proteolytic activity of $\mathrm{DINE}^{\mathrm{E} 613 \mathrm{~V}}$ was not completely abolished in vivo, although previous in vitro studies showed that such single point mutation of a glutamate residue in the catalytic HExxH motif did not exhibit proteolytic activity (Devault et al., 1988a; Shimada et al., 1996; Lee et al., 1999). The identification of DINE substrates will provide an exact answer in the near future.

The current study focused on the interaction between axons and Schwann cells during motor nerve development as a possible mechanism of DINE. Previous reports have defined several steps in the developmental progression of SCPs leading to Schwann cells (Jessen and Mirsky, 2005; Monk et al., 2015). During embryogenesis, SCPs comigrate with axons in the developing PNS, differentiate into immature Schwann cells, and align along the axon to initiate myelination. Although SCPs and immature Schwann cells are associated with axons, the detailed mechanisms remain unclear. Several studies have demonstrated that SCPs cover the growth cone at the nerve terminal and guide axons by controlling exposure to the extracellular environment (Wanner et al., 2006a, b). Raphael et al. (2010) found that Schwann cells assisted axons in invading the epidermal basement membrane in zebrafish. The findings suggest that SCPs and immature Schwann cells regulate axonal behavior during motor nerve development.

The majority of mice lacking the NMJ formation-related genes exhibit overarborization and overelongation of nerves in the diaphragm (Gautam et al., 1996; Okada et al., 2006; Yumoto et al., 2012). However, mice lacking SCPs exhibit similar phenotypes with DINE KO mice. ErbB2/3- or NRG1-deficient mice exhibit a complete loss or marked reduction of SCPs in the peripheral nerve, respectively (Riethmacher et al., 1997; Lin et al., 2000; Wolpowitz et al., 2000; Yang et al., 2001). The loss of SCPs in developing peripheral nerves results in axon defasciculation, followed by a defect in peripheral axon projection and neuronal death. A similar phenotype is also observed in Sox10-deficient mice (Britsch et al., 2001). Although these phenotypes are more severe than in DINE KO mice, it is likely that DINE protease activity is involved in the interaction between Schwan cells and axons that express DINE.

In DINE KO mice, NMJ formation occurs within a group of muscles in which primary or secondary branches of nerves are superficially located. The intercostal muscles, for instance, are 
A
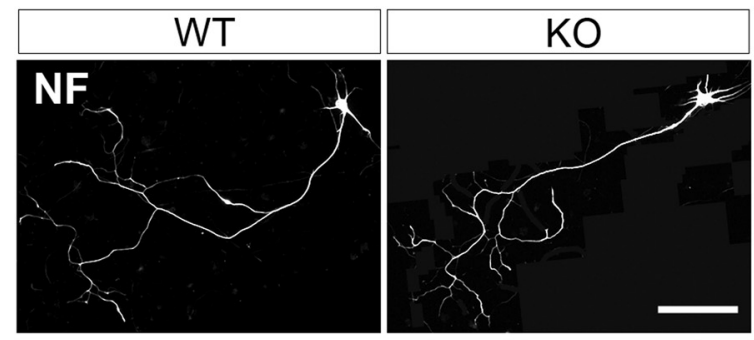

B

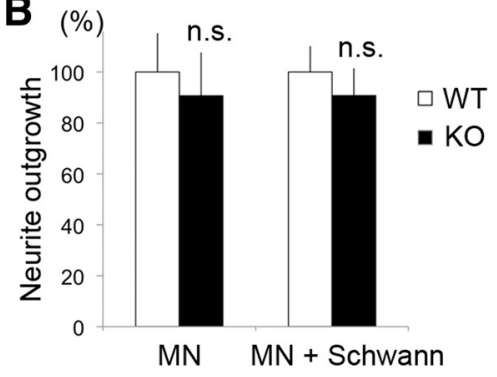

C

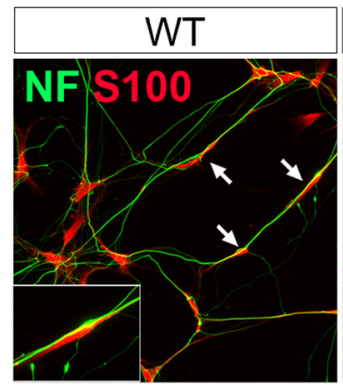

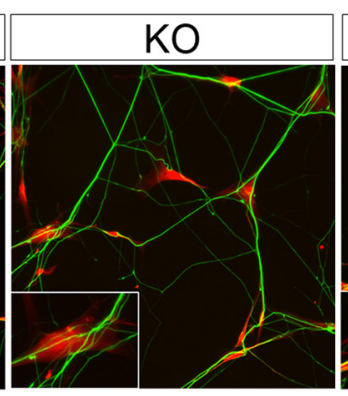
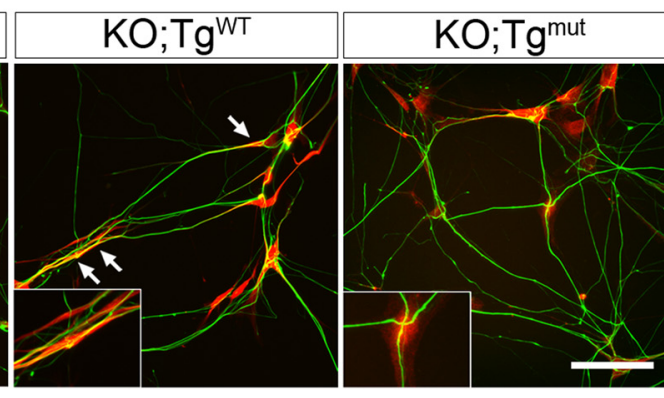

D

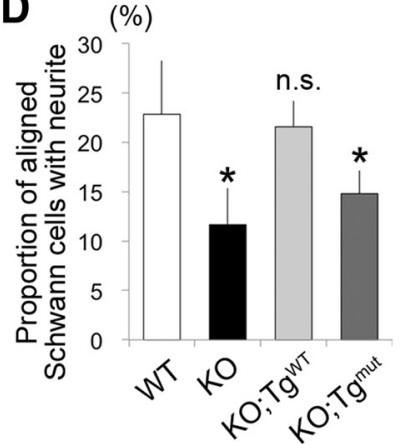

Figure 8. DINE deficiency demonstrates abnormal interaction between neurites and Schwann cells in vitro. A, Motor neurons from E12.5 embryos of WT and K0 mice were cultured for $3 \mathrm{~d}$ and immunostained by anti-neurofilament (NF) antibody. No obvious difference in morphology was identified. $\boldsymbol{B}$, In NF-labeled neurons, the length of the longest neurite from the cell body was measured before (left) and after (right) addition of separately cultured rat Schwann cells to the motor neuron culture. There were no significant differences in length of neurites before and after addition of Schwann cells. C, Motor neurons from WT, KO, KO; Tg ${ }^{\mathrm{WT}}$, or KO; $\mathrm{Tg}^{\text {mut }}$ embryos were cocultured with WT Schwann cells. Neurites and Schwann cells were stained with anti-NF (green) and anti-S100 (red) antibodies, respectively. Insets, High magnification of Schwann cells associating with neurites. $\boldsymbol{D}$, Proportion of aligned Schwann cells along neurites ( $\boldsymbol{C}$, arrows) was compared between $\mathrm{WT}, \mathrm{KO}, \mathrm{KO} ; \mathrm{Tg}^{\mathrm{WT}}$, and $\mathrm{K0} ; \mathrm{Tg}^{\text {mut }}$ mice. The proportion of aligned Schwann cells in coculture using motor neurons from $\mathrm{KO}$ and $\mathrm{K0}$; $\mathrm{Tg}^{\text {mut }}$ mice was significantly different from those in coculture using motor neurons from WT and K0; Tg ${ }^{\text {WT }}$ mice. The number of nonaligned Schwann cells was greater in K0 and K0; Tg ${ }^{\text {mut }}$ mice. ${ }^{*} p<0.05$. Scale bars: A, C, $100 \mu$ m. n.s., Not significant. Error bars indicate SD.

not drastically affected in DINE KO mice at E18.5 (Nagata et al., 2010). Similar differences in defect severity between phrenic and intercostal innervation have also been observed in ErbB2deficient mice (Lin et al., 2000), which could suggest that the depth of the final motor branches in a muscle correlates with more severely affected muscle innervation (Couesnon et al., 2013). In this respect, protease activity of DINE may be necessary for axons to penetrate deeper into muscle. After reaching the diaphragm, phrenic nerves are associated with extracellular matrix and/or membrane-associated fibers, such as collagens XIII/ XXV and laminin; collagen Type XIII and XXV are abundant in the NMJ and muscle, respectively, and their deficiencies affect NMJ formation and maintenance (Latvanlehto et al., 2010; Tanaka et al., 2014).

The present study examined the proteolytic role of DINE and the mechanisms involved in the differentiation of immature Schwann cells and their adhesion to axons. DINE is a membranebound metalloprotease that belongs to the NEP family, whose members cleave neuropeptides, such as amyloid- $\beta$, somatostatin, and endothelin (Yanagisawa et al., 1988; Barnes et al., 1995; Iwata et al., 2000). Previous studies were not able to show that DINE functions as a protease. However, results from the present study confirmed a role for DINE as a protease, although DINE could be an orphan metallopeptidase. It remains to be shown whether a substrate cleaved by DINE in axon might be involved in the maturation of immature Schwann cells and adhesion between axons and immature Schwann cells.

Multiple mutations in ECEL1 (human homolog of DINE) have also been found in human DA5D (Dieterich et al., 2013; McMillin et al., 2013). Recently, a mutation in the adhesion G-protein-coupled receptor GPR126 was identified in human ar- throgryposis (Glenn and Talbot, 2013; Ravenscroft et al., 2015). Further, GPR126 is associated with Schwann cell development (Mogha et al., 2013). Interestingly, activation of GPR126 signaling in Schwann cells is regulated by proteolysis to alter the binding effect with extracellular collagen and laminin (Paavola et al., 2014; Petersen et al., 2015). Although we did not address the possibility that DINE is involved in GPR126 activation in the present study, proteolytic regulation might influence the interaction between axons and immature Schwann cells, as well as subsequent NMJ formation.

In conclusion, results from the present study clarified that the DINE protease activity domain is critical for intramuscular axonal branching during the late embryonic stage. Proper interaction of motor axons with the external muscle environment is necessary to form robust nerve arborization and sufficient number of NMJs. DINE protease activity would be essential in processes, such as differentiation of immature Schwann cells and interactions between axons and Schwann cells or the intramuscular environment. The identification of a DINE substrate will help to elucidate new mechanisms that underlie nerve arborization in muscles and NMJ formation, as well as shed further light on the pathogenesis and treatment of motor neuron diseases, including DA5D, in which patients carry a DINE mutation.

\section{References}

Arber S, Han B, Mendelsohn M, Smith M, Jessell TM, Sockanathan S (1999) Requirement for the homeobox gene $\mathrm{Hb} 9$ in the consolidation of motor neuron identity. Neuron 23:659-674. CrossRef Medline

Barnes K, Doherty S, Turner AJ (1995) Endopeptidase-24.11 is the integral membrane peptidase initiating degradation of somatostatin in the hippocampus. J Neurochem 64:1826-1832. CrossRef Medline 
Birchmeier C (2009) ErbB receptors and the development of the nervous system. Exp Cell Res 315:611-618. CrossRef Medline

Britsch S, Goerich DE, Riethmacher D, Peirano RI, Rossner M, Nave KA, Birchmeier C, Wegner M (2001) The transcription factor Sox10 is a key regulator of peripheral glial development. Genes Dev 15:66-78. CrossRef Medline

Choi T, Huang M, Gorman C, Jaenisch R (1991) A generic intron increases gene expression in transgenic mice. Mol Cell Biol 11:3070-3074. CrossRef Medline

Couesnon A, Offner N, Bernard V, Chaverot N, Backer S, Dimitrov A, Perez F, Molgó J, Bloch-Gallego E (2013) CLIPR-59: a protein essential for neuromuscular junction stability during mouse late embryonic development. Development 140:1583-1593. CrossRef Medline

Devault A, Nault C, Zollinger M, Fournie-Zaluski MC, Roques BP, Crine P, Boileau G (1988a) Expression of neutral endopeptidase (enkephalinase) in heterologous COS-1 cells: characterization of the recombinant enzyme and evidence for a glutamic acid residue at the active site. J Biol Chem 263:4033-4040. Medline

Devault A, Sales V, Nault C, Beaumont A, Roques B, Crine P, Boileau G (1988b) Exploration of the catalytic site of endopeptidase 24.11 by sitedirected mutagenesis: histidine residues 583 and 587 are essential for catalysis. FEBS Lett 231:54-58. CrossRef Medline

Dieterich K, Quijano-Roy S, Monnier N, Zhou J, Fauré J, Smirnow DA, Carlier R, Laroche C, Marcorelles P, Mercier S, Mégarbané A, Odent S, Romero N, Sternberg D, Marty I, Estournet B, Jouk PS, Melki J, Lunardi J (2013) The neuronal endopeptidase ECEL1 is associated with a distinct form of recessive distal arthrogryposis. Hum Mol Genet 22:1483-1492. CrossRef Medline

Feng G, Laskowski MB, Feldheim DA, Wang H, Lewis R, Frisen J, Flanagan JG, Sanes JR (2000) Roles for ephrins in positionally selective synaptogenesis between motor neurons and muscle fibers. Neuron 25:295-306. CrossRef Medline

Freese C, Garratt AN, Fahrenholz F, Endres K (2009) The effects of alpha-secretase ADAM10 on the proteolysis of neuregulin-1. FEBS J 276:1568-1580. CrossRef Medline

Gatto G, Morales D, Kania A, Klein R (2014) EphA4 receptor shedding regulates spinal motor axon guidance. Curr Biol 24:2355-2365. CrossRef Medline

Gautam M, Noakes PG, Moscoso L, Rupp F, Scheller RH, Merlie JP, Sanes JR (1996) Defective neuromuscular synaptogenesis in agrin-deficient mutant mice. Cell 85:525-535. CrossRef Medline

Glenn TD, Talbot WS (2013) Analysis of Gpr126 function defines distinct mechanisms controlling the initiation and maturation of myelin. Development 140:3167-3175. CrossRef Medline

Haase G, Dessaud E, Garcès A, de Bovis B, Birling M, Filippi P, Schmalbruch $\mathrm{H}$, Arber S, deLapeyrière O (2002) GDNF acts through PEA3 to regulate cell body positioning and muscle innervation of specific motor neuron pools. Neuron 35:893-905. CrossRef Medline

Hu X, He W, Diaconu C, Tang X, Kidd GJ, Macklin WB, Trapp BD, Yan R (2008) Genetic deletion of BACE1 in mice affects remyelination of sciatic nerves. FASEB J 22:2970-2980. CrossRef Medline

Iwata N, Tsubuki S, Takaki Y, Watanabe K, Sekiguchi M, Hosoki E, Kawashima-Morishima M, Lee HJ, Hama E, Sekine-Aizawa Y, Saido TC (2000) Identification of the major Abeta1-42-degrading catabolic pathway in brain parenchyma: suppression leads to biochemical and pathological deposition. Nat Med 6:143-150. CrossRef Medline

Jessen KR, Mirsky R (2005) The origin and development of glial cells in peripheral nerves. Nat Rev Neurosci 6:671-682. CrossRef Medline

Kato R, Kiryu-Seo S, Kiyama H (2002) Damage-induced neuronal endopeptidase (DINE/ECEL) expression is regulated by leukemia inhibitory factor and deprivation of nerve growth factor in rat sensory ganglia after nerve injury. J Neurosci 22:9410-9418. Medline

Kiryu-Seo S, Sasaki M, Yokohama H, Nakagomi S, Hirayama T, Aoki S, Wada K, Kiyama H (2000) Damage-induced neuronal endopeptidase (DINE) is a unique metallopeptidase expressed in response to neuronal damage and activates superoxide scavengers. Proc Natl Acad Sci U S A 97: 4345-4350. CrossRef Medline

Kiryu-Seo S, Kato R, Ogawa T, Nakagomi S, Nagata K, Kiyama H (2008) Neuronal injury-inducible gene is synergistically regulated by ATF3, c-Jun, and STAT3 through the interaction with Sp1 in damaged neurons. J Biol Chem 283:6988-6996. CrossRef Medline

La Marca R, Cerri F, Horiuchi K, Bachi A, Feltri ML, Wrabetz L, Blobel CP,
Quattrini A, Salzer JL, Taveggia C (2011) TACE (ADAM17) inhibits Schwann cell myelination. Nat Neurosci 14:857-865. CrossRef Medline

Latvanlehto A, Fox MA, Sormunen R, Tu H, Oikarainen T, Koski A, Naumenko N, Shakirzyanova A, Kallio M, Ilves M, Giniatullin R, Sanes JR, Pihlajaniemi T (2010) Muscle-derived collagen XIII regulates maturation of the skeletal neuromuscular junction. J Neurosci 30:12230-12241. CrossRef Medline

Lee S, Lin M, Mele A, Cao Y, Farmar J, Russo D, Redman C (1999) Proteolytic processing of big endothelin-3 by the kell blood group protein. Blood 94:1440-1450. Medline

Le Moual H, Devault A, Roques BP, Crine P, Boileau G (1991) Identification of glutamic acid 646 as a zinc-coordinating residue in endopeptidase24.11. J Biol Chem 266:15670-15674. Medline

Lieberam I, Agalliu D, Nagasawa T, Ericson J, Jessell TM (2005) A Cxcl12CXCR4 chemokine signaling pathway defines the initial trajectory of mammalian motor axons. Neuron 47:667-679. CrossRef Medline

Lin W, Sanchez HB, Deerinck T, Morris JK, Ellisman M, Lee KF (2000) Aberrant development of motor axons and neuromuscular synapses in erbB2-deficient mice. Proc Natl Acad Sci U S A 97:1299-1304. CrossRef Medline

Matsumoto S, Konishi H, Maeda R, Kiryu-Seo S, Kiyama H (2012) Expression analysis of the regenerating gene (Reg) family members Reg-IIIbeta and Reg-IIIgamma in the mouse during development. J Comp Neurol 520:479-494. CrossRef Medline

McMillin MJ, Below JE, Shively KM, Beck AE, Gildersleeve HI, Pinner J, Gogola GR, Hecht JT, Grange DK, Harris DJ, Earl DL, Jagadeesh S, Mehta SG, Robertson SP, Swanson JM, Faustman EM, Mefford HC, Shendure J, Nickerson DA, Bamshad MJ (2013) Mutations in ECEL1 cause distal arthrogryposis type 5D. Am J Hum Genet 92:150-156. CrossRef Medline

Mogha A, Benesh AE, Patra C, Engel FB, Schöneberg T, Liebscher I, Monk KR (2013) Gpr126 functions in Schwann cells to control differentiation and myelination via G-protein activation. J Neurosci 33:17976-17985. CrossRef Medline

Monk KR, Feltri ML, Taveggia C (2015) New insights on Schwann cell development. Glia 63:1376-1393. CrossRef Medline

Nagata K, Kiryu-Seo S, Kiyama H (2006) Localization and ontogeny of damage-induced neuronal endopeptidase mRNA-expressing neurons in the rat nervous system. Neuroscience 141:299-310. CrossRef Medline

Nagata K, Kiryu-Seo S, Maeda M, Yoshida K, Morita T, Kiyama H (2010) Damage-induced neuronal endopeptidase is critical for presynaptic formation of neuromuscular junctions. J Neurosci 30:6954-6962. CrossRef Medline

Ohba N, Kiryu-Seo S, Maeda M, Muraoka M, Ishii M, Kiyama H (2004) Expression of damage-induced neuronal endopeptidase (DINE) mRNA in peri-infarct cortical and thalamic neurons following middle cerebral artery occlusion. J Neurochem 91:956-964. CrossRef Medline

Okada K, Inoue A, Okada M, Murata Y, Kakuta S, Jigami T, Kubo S, Shiraishi H, Eguchi K, Motomura M, Akiyama T, Iwakura Y, Higuchi O, Yamanashi Y (2006) The muscle protein Dok-7 is essential for neuromuscular synaptogenesis. Science 312:1802-1805. CrossRef Medline

Paavola KJ, Sidik H, Zuchero JB, Eckart M, Talbot WS (2014) Type IV collagen is an activating ligand for the adhesion $\mathrm{G}$ protein-coupled receptor GPR126. Sci Signal 7:ra76. CrossRef Medline

Petersen SC, Luo R, Liebscher I, Giera S, Jeong SJ, Mogha A, Ghidinelli M, Feltri ML, Schöneberg T, Piao X, Monk KR (2015) The adhesion GPCR GPR126 has distinct, domain-dependent functions in Schwann cell development mediated by interaction with laminin-211. Neuron 85 : 755-769. CrossRef Medline

Philippidou P, Walsh CM, Aubin J, Jeannotte L, Dasen JS (2012) Sustained Hox 5 gene activity is required for respiratory motor neuron development. Nat Neurosci 15:1636-1644. CrossRef Medline

Raphael AR, Perlin JR, Talbot WS (2010) Schwann cells reposition a peripheral nerve to isolate it from postembryonic remodeling of its targets. Development 137:3643-3649. CrossRef Medline

Ravenscroft G, Nolent F, Rajagopalan S, Meireles AM, Paavola KJ, Gaillard D, Alanio E, Buckland M, Arbuckle S, Krivanek M, Maluenda J, Pannell S, Gooding R, Ong RW, Allcock RJ, Carvalho ED, Carvalho MD, Kok F, Talbot WS, Melki J, et al. (2015) Mutations of GPR126 are responsible for severe arthrogryposis multiplex congenita. Am J Hum Genet 96: 955-961. CrossRef Medline

Riethmacher D, Sonnenberg-Riethmacher E, Brinkmann V, Yamaai T, Lewin 
GR, Birchmeier C (1997) Severe neuropathies in mice with targeted mutations in the ErbB3 receptor. Nature 389:725-730. CrossRef Medline

Roelink H, Porter JA, Chiang C, Tanabe Y, Chang DT, Beachy PA, Jessell TM (1995) Floor plate and motor neuron induction by different concentrations of the amino-terminal cleavage product of sonic hedgehog autoproteolysis. Cell 81:445-455. CrossRef Medline

Shimada K, Takahashi M, Turner AJ, Tanzawa K (1996) Rat endothelinconverting enzyme-1 forms a dimer through Cys412 with a similar catalytic mechanism and a distinct substrate binding mechanism compared with neutral endopeptidase-24.11. Biochem J 315:863-867. CrossRef Medline

Sumitomo M, Shen R, Nanus DM (2005) Involvement of neutral endopeptidase in neoplastic progression. Biochim Biophys Acta 1751:52-59. CrossRef Medline

Tanaka T, Wakabayashi T, Oizumi H, Nishio S, Sato T, Harada A, Fujii D, Matsuo Y, Hashimoto T, Iwatsubo T (2014) CLAC-P/collagen type $\mathrm{XXV}$ is required for the intramuscular innervation of motoneurons during neuromuscular development. J Neurosci 34:1370-1379. CrossRef Medline

Turner AJ, Tanzawa K (1997) Mammalian membrane metallopeptidases: NEP, ECE, KELL, and PEX. FASEB J 11:355-364. Medline

Wanner IB, Mahoney J, Jessen KR, Wood PM, Bates M, Bunge MB (2006a) Invariant mantling of growth cones by Schwann cell precursors charac- terize growing peripheral nerve fronts. Glia 54:424-438. CrossRef Medline

Wanner IB, Guerra NK, Mahoney J, Kumar A, Wood PM, Mirsky R, Jessen KR (2006b) Role of N-cadherin in Schwann cell precursors of growing nerves. Glia 54:439-459. CrossRef Medline

Wolpowitz D, Mason TB, Dietrich P, Mendelsohn M, Talmage DA, Role LW (2000) Cysteine-rich domain isoforms of the neuregulin-1 gene are required for maintenance of peripheral synapses. Neuron 25:79-91. CrossRef Medline

Yanagisawa M, Kurihara H, Kimura S, Tomobe Y, Kobayashi M, Mitsui Y, Yazaki Y, Goto K, Masaki T (1988) A novel potent vasoconstrictor peptide produced by vascular endothelial cells. Nature 332:411-415. CrossRef Medline

Yang X, Arber S, William C, Li L, Tanabe Y, Jessell TM, Birchmeier C, Burden SJ (2001) Patterning of muscle acetylcholine receptor gene expression in the absence of motor innervation. Neuron 30:399-410. CrossRef Medline

Yumoto N, Wakatsuki S, Kurisaki T, Hara Y, Osumi N, Frisén J, SeharaFujisawa A (2008) Meltrin beta/ADAM19 interacting with EphA4 in developing neural cells participates in formation of the neuromuscular junction. PLoS One 3:e3322. CrossRef Medline

Yumoto N, Kim N, Burden SJ (2012) Lrp4 is a retrograde signal for presynaptic differentiation at neuromuscular synapses. Nature 489:438-442. CrossRef Medline 